\title{
Riding the Wave: Daily Life and Religion among Brazilian Immigrants to Japan in the Age of COVID-19 Pandemic
}

\author{
Hugo Córdova Quero ${ }^{1, *}$ and Nilta Dias ${ }^{2, *}$ \\ 1 Starr King School, Graduate Theological Union, Berkeley, CA 94709, USA \\ 2 Faculty of Foreign Studies Sophia University, Tokyo 102-8554, Japan \\ * Correspondence: hquero@sksm.edu (H.C.Q.); n-dias@sophia.ac.jp (N.D.)
}

Citation: Córdova Quero, Hugo, and Nilta Dias. 2021. Riding the Wave: Daily Life and Religion among Brazilian Immigrants to Japan in the Age of COVID-19 Pandemic. Religions 12: 943. https://doi.org/10.3390/ rel12110943

Academic Editor: Glenda

Tibe Bonifacio

Received: 5 August 2021

Accepted: 21 October 2021

Published: 29 October 2021

Publisher's Note: MDPI stays neutral with regard to jurisdictional claims in published maps and institutional affiliations.

Copyright: (c) 2021 by the authors. Licensee MDPI, Basel, Switzerland. This article is an open access article distributed under the terms and conditions of the Creative Commons Attribution (CC BY) license (https:/ / creativecommons.org/licenses/by/ $4.0 /)$.

\begin{abstract}
In March 2020, the world folded before an imminent pandemic. Community gatherings, events, and rituals quickly moved online. Jobs halted or were conducted remotely. The fear of the COVID-19 pandemic impacted different areas of daily life. In this article, we propose examining and analyzing the experiences and narratives of Brazilian migrants in Japan. With the Immigration Control and Refugee Recognition Act amendment on 8 December 1989, thousands of Japanese descendants born and raised in the Americas migrated to Japan. They are the offspring of Japanese immigrants who established colonies in the Americas in the late nineteenth and early twentieth century. Over time, the community of Brazilian immigrants in Japan fluctuated from being a minority to become the fifth-largest ethnic group of immigrants. Our analysis focuses on two areas of concern in times of the COVID-19 pandemic: daily life-including gender, and religion. On the one hand, daily life became cumbersome due to issues related to language and the hardships of accessing health services in a foreign land. On the other hand, we state that in the process of adaptation to the new society, the role of faith communities has been notable in offering support to these immigrants. Religious institutions, in particular, confronted the fact of moving their support and activities online with the consequent difficulties for those who are not tech-savvy or lack reliable connectivity. Both situations impacted Brazilian immigrants in different ways during the COVID-19 pandemic and highlighted the agency they displayed in coping with its consequences.
\end{abstract}

Keywords: Brazilian immigrants; Japan; COVID-19 pandemic; transnational migrations; religions

\section{Introduction: How the Story Began}

Japanese authorities detected the first case of COVID-19 in early January 2020. According to media reports, the first case was a man of Chinese nationality living in Kanagawa Prefecture who returned from Wuhan on January 6 and was hospitalized on January 10 (Kyodo Staff Reporter 2020). Japan also dispatched charter flights to extract and evacuate Japanese nationals from Wuhan. In the first flight, tests already confirmed that some had contracted the virus (Takenaka 2020). In February 2020, the Diamond Princess cruise ship arrived in Yokohama harbor with approximately 3700 people on board and remained in quarantine, which also caused other ports in Japan, such as Naha, to panic regarding the visit of the ship (Osumi 2020). The Japanese government took numerous steps but failed to create immediate and effective measures to prevent and impede the spread of the virus, including failing to administer additional tests and monitor those who disembarked from the ship (Reuters 2020).

It was even challenging to impose measures regarding mandatory examinations and quarantine. According to a report published by the Correio Braziliense newspaper (Agência France Presse 2020), two Japanese people removed from Wuhan refused to undergo exams when they arrived in Tokyo. According to the newspaper, the Minister of Health Katsunobu Kato said: "We explained that the tests could help them, but these people are not convinced. We do not have the legal basis to force them to accept the tests" (Agência France Presse 
2020). Thus, little by little, cases of contagion by Coronavirus were gradually increasing in Japan. The "Summary of The White Paper on Land, Infrastructure, Transport, and Tourism in Japan, 2020" states that by May 2020, there were already 16,884 cases in Japan (Ministry of Land, Infrastructure, Transport and Tourism of Japan 2020).

The public critiqued the Japanese authorities about delaying taking action or ineffective measures to control the COVID-19 pandemic (Suzuki 2020). The heavy criticism of some decisions affected Prime Minister Shinzo Abe's popularity. One example was the distribution of fabric masks to the population (Figure 1). The use of masks is usual among the Japanese, and with the increase in cases of COVID infections, this product has literally "disappeared" from supermarket and pharmacy shelves. To alleviate the problem, the government created a project to distribute washable masks. The government allocated a kit with two fabric masks via mail to all families, including foreign residents. According to an article published by the Japanese newspaper The Mainichi Shimbun (2020):

It took about two months for the government to deliver the masks, dubbed

"Abenomasks", a pun on the "Abenomics" economic policy mix promoted by the

Abe administration, after the nationwide delivery contracted out to Japan Post began on April 17. (Akiyama 2020)

The main criticisms regarding the "Abenomasks" related to the project's high cost and low effectiveness, as reported by Kyodo News (2020): “The project cost the government 26 billion yen ( $\$ 247$ million), with 18.4 billion yen spent on procurement and 7.6 billion yen on delivery". In addition to solid criticism, this measure was the reason for many jokes (memes) over social media (Osaki 2020). That demonstrated the ineffectiveness of the project and evidenced the discontent of the population.
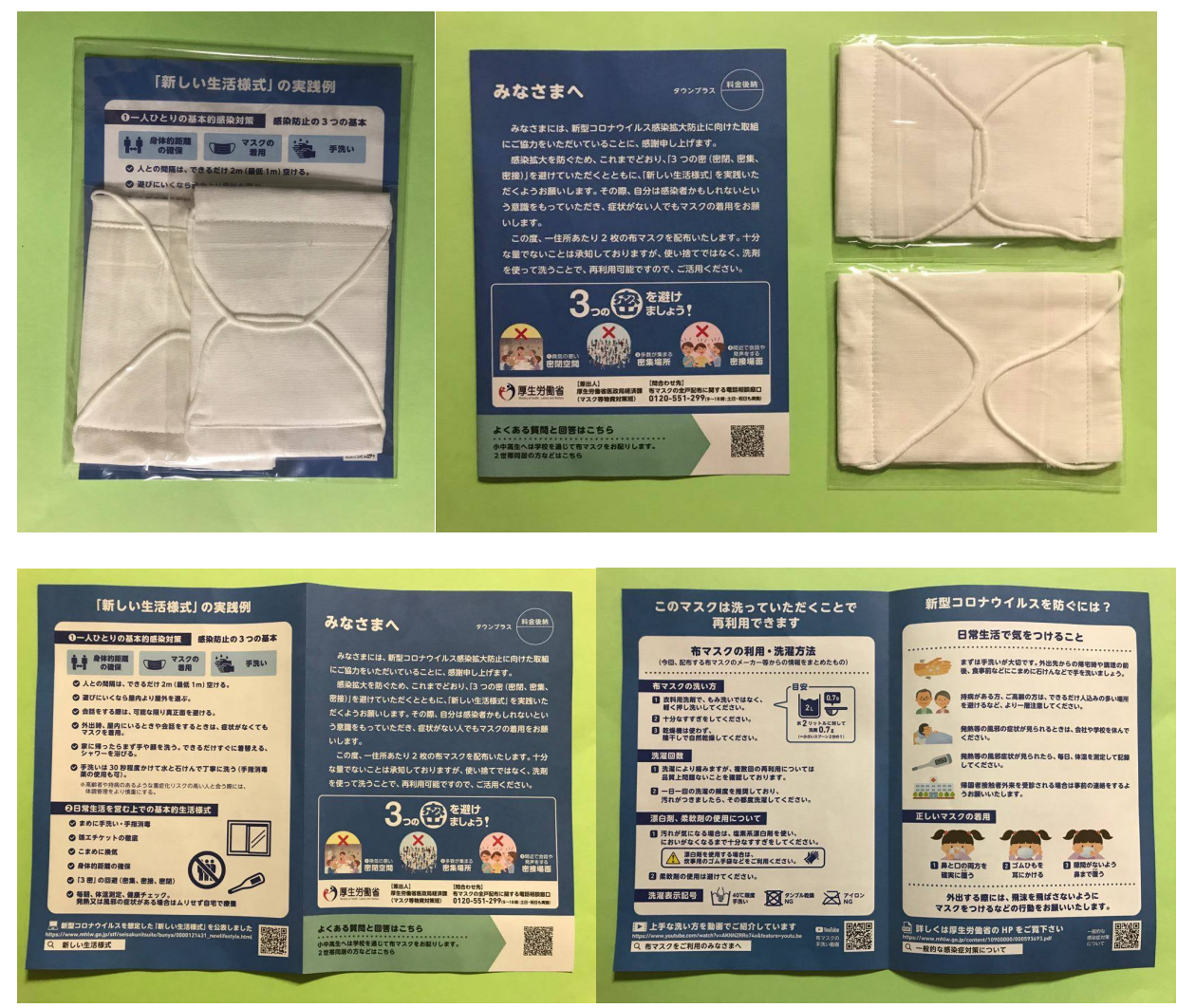

Figure 1. Package with masks distributed by the Ministry of Health of Japan. Source: Authors' archive.

Much more sensible was the measure regarding emergency financial assistance. In April 2020, as part of the emergency economic package to tackle COVID-19, the Japanese 
government announced a subsidy of JPY 100,000-about USD 1000-to residents of Japanese territory (Busetto 2020). This emergency aid-granted to all persons without age restriction-included all foreign residents registered with the prefectures of their places of residence.

Shinzo Abe resigned due to illness and officially stepped down as Prime Minister of Japan on 16 September 2020 (Shimada 2020), and Yoshihide Suga took over as his successor (BBC 2020b). However, since the postponement of the 2020 Olympic Games to 2021, Tokyo's governor, Yuriko Koike, is always present on the news. The COVID-19 pandemic and the hosting of the Olympics ended up becoming two major inseparable problems because the pandemic threatened to make it impossible to hold the games. Thus, holding the Olympic Games-considering the number of participants and the inevitable clusters and contacts-increased the risk of further propagation of the virus. The reality behind the new wave of contagions became invisibilized due to the Olympics (Takahashi 2021).

Since the pandemic's beginning, the Japanese government has taken measures, but always in a very thoughtful way and without impositions. That, in turn, created an atmosphere of apparent "control" of the situation. In 2020, the Japanese government debated itself between the state of emergency and "states of nearest emergency", yet there was no lockdown mandatory nationwide. Japan also relied upon the custom of using surgical masks, a widespread practice in the country (Suppasri et al. 2020), along with other hygiene practices such as removing the shoes when entering a home. Nonetheless, the government has always asked the population to avoid clusters.

Many tourists returning from abroad were instructed not to use public transport and stay at their homes or in a hotel upon arrival in Japan. As Brazil is one of the countries with restrictions to enter Japan, the webpage of the General Consulate of Japan in Consulado Geral do Japão em São Paulo (2021) informs about those restrictions to possible travelers:

All persons entering or returning from Brazil will be inspected at the airport. Then, we will take them to facilities designated by the Quarantine Department and retest them on the third day after entry (note). Those who test negative will be allowed to leave the designated facility and complete the remainder of the 14-day quarantine (grade) at home. We emphasize that you will not be allowed to use public transport to leave the facilities designated for your residence.

This information joins the guidelines announced by the Ministry of Foreign Affairs of Ministry of Foreign Affairs of Japan (2021). Still, there was no type of inspection to make sure that the returnees followed these guidelines. During that period, it was common to hear foreign residents questioning what Makiko, one of our interviewees, states: "How do the Japanese authorities think that a foreigner will arrive in Japan and be able to leave the airport without using public transport? Do they honestly believe that people-domestic or foreign - stay at home to wait whether they will have some symptoms of COVID?" As time passed, the situation worsened and the authorities reformulated or created rules, mainly concerning border control.

From the beginning of the pandemic, there was a tendency to be concerned with prevention. However, that entailed considering foreigners as a point of contagion much more than nationals. From the first measures relating to control at ports and airports concerning passengers returning from abroad, it was evident that the idea of "foreigners as a source of contagion" was the common assumption. That trend ended up fostering situations of prejudice and discrimination that are increasingly evident. Yet, it followed the same pattern of other moments in which Japanese society blamed foreigners for the spread of HIV (Talmadge 1996; Sato et al. 2001; Córdova Quero 2014) or the increment of delinquency amidst Japanese society (Córdova Quero 2010). Foreigners as scapegoats are a common feature in Japan.

In this article, we focus on the concern surrounding the COVID-19 pandemic when challenging daily life issues. If the situation affected nationals in Japan, it complicated the already complex lives of Brazilian immigrants. If the situation was problematic before the pandemic, Brazilian immigrants have resorted to different modes of connectedness, 
to the extent that quarantined bodies frequently hedge against stability, misnaming, and displacement; their "virtuality" becomes a pivotal site of connection. When bodies shift into the virtual, we encounter a creative performance of otherness. On the other hand, it also entails reconfiguring other aspects such as religions and sacramental practices, with its reexamination of theological practices, concerns around pastoral accompaniment, and observing how "vulnerable bodies" shift and transform across shared time and geography. Yet, the denial of the dangers of Coronavirus negatively colluded with fundamentalist notions of divine intervention, especially among Evangelical Neo-Pentecostal churches.

Given that context, the authors conducted virtual fieldwork inquiring about the reality of immigrants in times of pandemic regarding different areas, including religion and spirituality. According to Louise Scoz Pasteur de Pasteur de Faria (2020), the existence of social distancing and prevention of contagion implies a challenge to traditional research:

In a time where social research has to go through a significant methodological change to conform to current limitations, which will have an impact on the future of the field itself, it is indeed not the right time to make bold statements. Many researchers are not yet equipped to deal with these ethical and technological novelties. It can be a daunting experience ( ... ) .

Therefore, our fieldwork for this ongoing research includes in the first phase virtual interviews with ten informants through video telephony and online chat platforms, as well as an instant messaging and voice-over IP application. The ages of our interviewees range from 18 to 50 years old. Six of them are women, and four of them are men. All of them were born in Brazil and have been in Japan for a significant time. In the case of one of the interviewees, she came to Japan as a child and underwent all her education in the Japanese school system, which is not the reality of most Brazilian children, who generally attend Brazilian schools in Japan. Our ongoing research on this topic began in March 2021, and this article features some preliminary findings. Currently, we are in the second phase, which includes another group of ten interviewees and possible in-site participant observation if the social distancing and health ministry recommendations allow for that.

\section{Tracing the Origin: Why Brazilians Immigrants in Japan?}

Since the mid-1980s and the so-called "bubble economy", Japan has received an increasing number of immigrants, including thousands of ethnic Japanese from the Americas. Although most immigrants come from Brazil, they also include Peru, Bolivia, Argentina, Paraguay, or the United States, among other countries. These descendants of Japanese emigrants to the Americas challenge the paradigm of conflated national and racial identity in Japan as foreign nationals with a shared Japanese background. Usually referred to as Nikkeijin in Japan, these immigrants have varying ability levels in the Japanese language and exposure to Japanese culture and society. In some ways, the host society considers them similar to the Japanese people, while in other ways they are not.

The modern construction of Nikkeijin intersects with the notion of Nihonjin - ethnically Japanese citizens of Japan — and dekasegi, a term used initially to describe Japanese labor migrants in the late nineteenth and early twentieth centuries (Yamashiro 2008). Thus, the migratory movement of Japanese Brazilians to Japan is also known in Portuguese as the movimento dekassegui, which intensified in the mid-1980s (Linger 2001; Roth 2002; De Carvalho 2003; Higuchi and Tanno 2003; Tsuda 2003). The economic crisis in Brazil was one of the main factors that motivated this migratory flow, mainly because Japan was experiencing significant economic growth (Tsuda 2003; Córdova Quero 2008, 2009). As the Japanese economy flourished in the mid-1980s, Japan became a place that attracted migrants, including the descendants of earlier Japanese emigrants.

Labor migrants from neighboring countries in Asia began to seek out unskilled work in Japan, and in an attempt to control the flow of movement-and, more importantly, its supposed ethnic homogeneity - the Japanese government revised its immigration law in 1990 to allow ethnic Japanese to obtain legal entry to Japan. The reform of the Japanese Immigration Control Act came into effect in June 1990 and established the visa category 
called "residents for an extended period" for Japanese descendants up to the third generation (Tsuda 2003). That was an excellent incentive for thousands of Brazilians-especially those who have Japanese ancestry-to decide to leave Brazil for Japan. With the possibility of staying longer, the number of immigrants accompanied by spouses and children increased significantly. The result of this "Nikkeijin visa"—as is it colloquially known among migrants and scholars—-was that ethnic Japanese from the Americas, especially Brazil, migrated to Japan in waves, providing Japanese businesses with a supply of unskilled labor. Over the last 32 years, that measure- based on their ethnic ancestry-has benefited those Japanese descendants seeking to become Japanese citizens since this nation recognizes the jus sanguinis (blood right) as a way of granting citizenship to the second generation - niseiand the third generation—sansei—of Japanese descendants (Tsuda 2000, p. 40, note 1). To obtain citizenship, it is also necessary to have a good knowledge of the Japanese language -knowing how to speak, read, and write well, in addition to other requirements. Concurrently, the Brazilian immigrants were offered a low-cost, temporary, and not always trained workforce as incentives while guaranteeing - even if only hypothetically-to maintain the racial homogeneity of the Japanese society (Córdova Quero 2009, 2014).

In 1988, there were 4159 immigrants of Brazilian nationality registered in the registry of foreigners in Japan. By 1989, this number rose to 14,528. In 1990-with the immigration law reform - that figure doubled to 119,333 (Yamanaka 2003, p. 180). By the end of 2007, shortly before the economic crisis resulting from the Lehmans Brothers case, there were 316,967 Brazilian immigrants in the country (Ministry of Justice of Japan 2007). However, after that crisis and the Tohoku earthquake and tsunami in 2011, only 173,437 Japanese Brazilian residents were registered (Ministry of Justice of Japan 2015), implying a 54\% reduction in this population in eight years. According to the Ministry of Justice of Japan (2020), there are currently 208,798 Brazilians residing in Japan.

Of the numerous problems Brazilian immigrants face in Japan, sociocultural adaptation is prominent because it directly or indirectly influences other aspects of daily life. Although most Brazilian immigrants are of Japanese descent, few are fluent in Japanese and suffer from cultural differences. In this sense, sociocultural adaptation represents a significant challenge (Yamawaki 2007; Córdova Quero et al. 2008), which becomes ever more complex for spouses who do not have Japanese ancestry.

\section{Brazilians Immigrants and the Role of Religion Amid Their Lives}

\subsection{Migration and Religion}

One of the areas where the lives of Brazilian immigrants are affected in Japan resides in how to express religious beliefs. Resembling the spiritual map in Brazil, many and varied expressions of beliefs can be found among them. Although it could be fair to affirm that most Brazilian immigrants are Roman Catholics, many other Christian denominations and other religions count them as members. Historically, most Japanese who migrated to Brazil professed either Shinto or Jōdo Shinshū Buddhism as their religious belief. However, in the process of integration into Brazilian society, it was inevitable that some experienced conversion to Christianity, to Afro-Brazilian religions such as Umbanda, Kimbanda, and Candomble, or other faiths. Among the many branches of Christianity, Japanese descendants in Brazil attend the Roman Catholic Church, the Episcopal Church, many Protestant Churches, and Pentecostal churches. In the last three decades, they are also present within new religious movements (NRM) such as the Igreja Universal do Reino de Deus (The Universal Church of the Kingdom of God). They also remain active in Jōdo Shinshū Buddhism, Shinto, and Japanese New Religious Movements such as Soka Gakkai and Sekai Kyuseikyo (Church of World Messianity) (Matsuoka 2004, 2007) or Seicho-no-iê (Matsue 2003, 2006; Pye 2011).

When Brazilian immigrants move to Japan, they bring their religious beliefs, too. At present, Christians in Japan count as around one million. Migrants from Latin America and Filipino and other ethnic groups constitute the majority of Christians in Japan (Mullins 2006; Córdova Quero 2007, 2008, 2010; Córdova Quero and Shoji 2014). However, the lack of 
information about the number of immigrants within religious organizations is paradoxical. In more extensive Japanese society, statistics and information from the registration system constantly report about the total number of foreign residents at national and local levels. Nonetheless, Juliana Sayuri (2020) offers the following information:

According to the 2019 Shukyo Nenkan, the annual religious report of the country's Cultural Affairs Agency, there are 84,000 Shinto (46.9\%), 77,000 Buddhist $(42.6 \%)$, and 4700 Christian (2.6\%) active organizations. There are also 14,000 organizations of other religions $(7.9 \%)$ not identified by name. Nor are there any distinctions between Roman Catholic and Evangelical Christian churches.

Furthermore, Córdova Quero (2013) has observed that the scarce interaction between nationals and foreigners within the same parish results in the full inclusion of immigrants in the life and statistics of that Christian branch. One characteristic of Christianityparticularly Roman Catholicism - and other religions that have memberships in both countries is that the need for exclusively ethnic churches or temples does not exist. However, that does not necessarily transmit in the broad welcoming of immigrants. As in other ethnic groups in religious organizations, Japanese nationals and Brazilian members coexist in the same place. Nonetheless, except for a few places, most churches, parishes, and temples show the reality that the interaction of both groups is almost nonexistent. The tendency is to keep religious ceremonies in different languages at different times and on other days, thus enhancing the scarcely low contact between nationals and foreigners. Furthermore, immigrants' limited time and space for activities at local levels also transform their religiosity. Minimal interactions between citizens and foreigners in religious organizations constitute an ordinary situation that parallels those also observed at factories where, for example, nationals and immigrants eat at different tables during lunch break (Roth 2002, p. 46; Tsuda 2003, p. 16).

In few places, representatives from the ethnic communities are present in the local body of government of religious congregations. However, their role is to transmit back to their ethnic groups those decisions taken by Japanese nationals. The exceptions to these situations are those places where citizens and foreigners have managed to integrate their activities. They represent the minority of cases. What they have achieved is integration around a particular social project (Córdova Quero 2007, p. 37). Nevertheless, the process has been slow and colored by the different obstacles that they have overcome.

Notwithstanding, within the ethnic space of religious communities, the benefits for the migrants are significant at large. In analyzing the case of Roman Catholicism, Córdova Quero (2008) found that the Roman Catholic Church and other religious institutions maintain at least a three-fold role concerning the migrants.

First, the Roman Catholic Church offers the newcomers a space to speak their language, reproduce their culture, and where their peers and religious leaders understand their daily life situations. For immigrants who have recently left their own country and culture and separated from relatives and friends who guarantee social and emotional support, these are tremendous contributions. Thus, their interactions in the sacred space counter feelings of anomie, loneliness-or Saudade, as Brazilians call it in Portuguese, and isolation in a strange land. Thus, it facilitates the role of socialization into an individual's community in the diaspora.

Second, the space of the Roman Catholic Church becomes a bridge fostering connections with the broader social networks such as international programs at the city or town level, legal information, counseling, or contact with health organizations, among many others. That constitutes an important step into adjusting to life in Japan, at least allowing immigrants to connect to those sectors of society related to their daily lives. It also implies for those organizations within the Roman Catholic Church serving the immigrants to navigate the complex waters of the Japanese legal system, which increasingly emphasize "regulation" and "control" (Kawaguchi 2007, p. 97). Thus, the Church helps immigrants to face different situations in daily life. 
Third, the Roman Catholic Church, which deals with people's faith, fulfills the inner/existential dimensions that allow Brazilian migrants to maintain spiritual well-being. Charles Hirschman 4 has pointed out that migrants tend to become more religious in the host society. He states:

Customary religious practices, such as attending weekly services, lighting candles, burning incense in front of a family altar, and reciting prayers are examples of communal and family rituals, which were brought from the old country to the new. However, these activities often take on new meanings after migration. The normal feeling of loss experienced by immigrants means that familiar religious rituals learned in childhood, such as hearing prayers in one's native tongue, provide an emotional connection, especially when shared with others. These feelings are accentuated from time to time with the death of a family member or some other tragedy. ( ... ) [R]eligious beliefs and attachments have stronger roots after immigration than before (p. 1211).

The findings of Córdova Quero (2008) could also help us understand the exact situation regarding religions different from Christianity. Although immigrants reach out to religious organizations for their social services and networking - also offered by non-profit organizations (NPOs), another aspect that attracts them is caring for their spiritual wellbeing. Nonetheless, the degree to which immigrants reach the religious experience varies from individual to individual. Not every person relies on their faith experiences or is prone to become a spiritual leader. However, with the strength and support coming from those organizations, most people start to adjust to Japanese society in different degrees.

\subsection{Migration, Religion, and Gender}

Religious discourses are intrinsically related to cultural and social constructs, shaping the perception of gender, bodies, and sexuality. In this regard, religious organizations may present themselves as both a support and a challenge in terms of issues related to gender and sexuality among immigrants. Immigrants concurrently negotiate gender expectations in the host society while often conforming to gender expectations based on religious beliefs. Although this is beneficial in some cases, others may result in the reification of cis-heteropatriarchal normativities. Although individuals themselves are not always aware, cultural mediation is how one lives out religion and gender. Commonly, cultural and social constructions of gender are legitimized and reinforced through specific religious beliefs, as are the contours of sexuality.

Contemporary definitions of gender-role expectations, the cis-heteropatriarchal sexual division of labor, or the norms pertaining to decency and morality have been socially, historically, and culturally constructed over time. In every society where a particular religion is hegemonic, its teaching has certainly influenced those definitions. Although Christianity in the West has been primarily hegemonic, a similar situation to-for exampleConfucianism in China, Hinduism in India, Buddhism in Japan, or Islam in the Middle East, among many other religions. The modern notion of the "heterosexual monogamous nuclear family" in the West originated in association with the teachings of the Protestant Reformation (Nussbaum 1997, p. 31).

Furthermore, religious beliefs have also benefited from cis-heteropatriarchalism by framing the Divine in masculine terms; a fact hindered until the rising of Feminist Theology (Radford Ruether 1993, p. 117; Schüssler Fiorenza 1994, p. 130). Culturally reified heteropatriarchalism interacts directly with religion, as religious practices are deeply rooted in cultural settings (Hirschman 2004, p. 2). Thus, intertwining migration with religion, gender, and sexuality highlights spaces of resistance, (re)negotiation, and (re)construction in the experience of transnational immigrants that challenge the "traditional" patterns in the host society. Globalization has accelerated contact among different cultures through transnational and transcultural migration at the individual, family, and community level, and religious organizations incarnate important roles amidst their lives. Thus, religious 
discourses-in general—-tend to conflate migration, gender, and sexuality within the cisheteropatriarchal framework (Córdova Quero 2016).

One of the findings in our research is the preponderant role that women have taken in their religious spaces. We observed how they play a leading role within the religious institution to which they belong and in society together with the people who profess that faith. The cis-heterosexual division of labor is that they divide their time and activities between work, household demands, and spiritual activities. As noted in Section 6 of this article, a particular characteristic of the respondents is that they are fluent in Japanese. That is not, however, the experience of most of the women. As we analyze in the following section, many have to overcome linguistic and cultural barriers to carry out their activities, including their spiritual practices.

\section{Multicultural Interactions in Times of COVID-19}

Living in a multicultural context is not always positive and pleasant. The ideal of multicultural coexistence entails respecting differences, learning to live together, and enjoying an environment marked by diversity in the broadest sense of the word. However, living in that multicultural context frequently faces situations where people see variety positively while others see it negatively. Even more, those who do not have an opinion sometimes act according to the influences of the environment (Córdova Quero 2007, 2009).

Although not a broader feature of Japanese society, since the beginning of the "dekassegui movement", it is possible to observe and verify some cases of prejudice against foreigners, primarily through the mass media (Tsuda 2003; Córdova Quero 2009). Since the first coronavirus cases appeared in Japan - which made evident that those infected were Chinese - the idea that foreigners are the ones who transmit the virus has caused uneasiness among many foreign residents in Japan. Indeed, it is impossible to generalize and assert that all Japanese think that way, but facts of everyday life prove that prejudice exists. As we can see in the newspaper article entitled "Ibaraki health center warns people not to eat with foreigners to prevent spreading COVID" (Kiko 2021), the discrimination did not only happen individually but started from a health center in the form of an official document. According to the newspaper article, "The document said that: 'There are many patients infected with COVID that likely caught it from foreigners.' In addition, to warning people from eating with foreigners, they also recommended: 'To please wear a mask when speaking with foreigners'" (Kiko 2021).

The Ibaraki health center later apologized and said that it had no intention of discriminating against foreigners. In this specific case, Hachima Kiko (2021) introduces testimonies from Japanese readers who prove that prejudice is not widespread:

“Despite that apology and retraction, it's still mind boggling where the original wording came from. All of this could've been easily avoided if the health center had just advocated for people to not eat out together in general, and to just wear a mask in general, not specifically pointing out foreigners".

Japanese netizens mostly had similar reactions:

"Discrimination".

"Just tell everyone to wear a mask and not eat out. Doing otherwise is discrimination".

"This just causes more discrimination against foreigners who lived in Japan before COVID, and Japanese people with foreign relatives".

"I mean, by foreigners, they're not including Westerners".

"This is the country that's going to be hosting the Olympics soon?"

"In an age where ridiculous misinformation about foreigners can spread easily, and taking back that misinformation and replacing it with the truth can be incredibly difficult, it's at least good to see a somewhat happy ending here. Let's 
hope that unfortunate notices likes these won't need to be retracted in the future, since they just won't happen in the first place".

Even before this report, some factories with many foreigners also acted in a prejudiced and discriminatory manner. For example, Alexandre-one of our interviewees-told us that some situations among workers emerged concerning the pandemics. He claimed that in the factory where he works, many foreign workers took the first COVID-19 tests. According to Juliana Sayuri (2021), the Brazilian Consulate in Hamamatsu received three anonymous letters protesting against Brazilian Olympics teams in Hamamatsu. Another case was a hotel in Tokyo that established different elevators for Japanese and foreigners (Kyodo News 2021). Although considered "isolated cases", we cannot ignore them because-directly or indirectly - these and other episodes may contribute to new cases of prejudice and discrimination.

On the other hand, we also observe that many people and institutions-mainly nonprofit organizations or NPOs-dedicate themselves to promoting cultural exchange and contributing to a better understanding of cultural differences. In difficult times such as a pandemic, many foreigners-depending on the location-rely on the support they can access from different Japanese instances. The Japanese government has created emergency measures for financial aid to the population. The labor law also guarantees some rights in case of layoffs or collective vacations during the pandemic. However, economic difficulties directly affected many Japanese and foreigners who-for different reasons-were left without a job or had a significant reduction in monthly income. In these situations, it is common for many immigrants to be in more vulnerable conditions when they live in an unstable socioeconomic reality. The economic impact directly reflects the daily consumption routine, including the lack or poor conditions to buy food. Since many people are in need, Japanese and foreign volunteers dedicate time and effort to helping them in whatever way possible. Some of those efforts involve distributing food and essential products, which became an everyday activity in different locations.

While considering the above, generalizing or enhancing stereotyped ideas related to prejudice is unhealthy and prevents us from seeing the situations that face my immigrants. There are discrimination cases, but there are also have examples of respect and solidarity.

\subsection{Lost in (the Lack of) Translation? Health Care and Vaccination Amidst the COVID-19 Pandemic}

The Japanese language is a big challenge and often a significant barrier for many foreigners living in Japan. Some foreigners dominate the conversation but cannot read and write due to the complex writing system of three types of character sets: hiragana, katakana, and kanji. Furthermore, the situation has led Brazilian immigrants to foster their way of dealing with Portuguese and Japanese daily by creating a mix of both languages, which Nilta Dias (2015) labeled as dekasseguês. For these immigrants, in many cases, the pandemic situation has turned into a major communication problem. Before the pandemic, many foreigners did not face significant difficulties communicating or solving professional or day-to-day issues. Notwithstanding, amidst the pandemics, they found themselves unable to carry out many tasks previously solved over the phone or in-person using oral language. Many services are now exclusively online and usually with the Japanese language as the only option. In addition, daily contact at work is now via email-usually in Japanese.

In some situations, Japanese people understand foreigners' circumstances as a personal issue, and only for foreigners who do not speak Japanese. Still, this predicament is much more complex in certain conditions. One example is the reservation system for receiving the COVID-19 vaccine created by the Japanese government. A card distribution system was designed with a number to identify the person who would receive the vaccine. The city hall sends this card. When receiving the card, the person would follow the instructions to make their reservation, marking the vaccination's place, date, and time. It sounds simple, but the difficulty is that each city carries it out differently. Cities with large concentrations of foreigners sought to simplify the process to avoid major problems. 
For example, they made written newsletters available in foreign residents' languages or created a call center service for assistance in different languages. However, in other cities where the number of foreigners is not representative, the local authorities are not prepared to assist those who do not speak the Japanese language. That, in turn, renders immigrants lost in the lack of translation.

Where one of our informants lives, the city government gave the vaccination card and written material or announcements by loudspeakers exclusively in Japanese. After receiving the card, the person should verify the reservation date, established according to age. That information is also available on the city's homepage or in the city's newsletter. According to the date, the reservation is only available by phone or directly over the internet. Everything seems very simple. Notwithstanding, having access to the basic information necessarily requires a person to read or speak Japanese if they choose to make the reservation over the phone. Our informant contacted the city hall to find out if there was any material in Portuguese and received information that there was a call center-in different languages-just for general information but not to explain how the system works in the city where he lives.

Afterward, with the help of foreign friends, our informant managed to understand what he should do and, after several attempts, managed to enter the page to make the reservation. The page was simple, but it took him more than two and a half hours to make the reservation because he could not understand the instructions written in Japanese. He only managed to make the reservation because he had the help of a friend who was conducting the translation through the photos sent by cell phone. In this case, immigrants who do not master Japanese reading and writing would not make a reservation, thus preventing them from accessing the vaccination. However, the difficulties continued for our informant because he needed to submit a questionnaire with information regarding his health status when attending the appointment for vaccination. That information included disclosing any prescribed medication, describing any undergoing health treatment, listing any allergy, and consent to receive the COVID-19 vaccine, among other questions. That form was also entirely in Japanese.

The friend who conducted the translation over the phone also alerted our informant regarding a translation of that questionnaire. Our informant did not know that a Portuguese translation is available on the Brazilian Consulate and the Ministry of Health in Japan. Concurrently, some cities have also provided translations to their netizens. Even so, he decided to ask the city hall and the hospital where he regularly undergoes treatment. It was frustrating for him to know that the call center's employee who attended him over the phone and the hospital employees who asked for information were unaware of the translation work carried out by the Ministry of Health of Japan. Although they were all very kind in their service, it transpired that they were unable to inform about translation services because the Ministry of Health had failed to disseminate that information to them. That shows that, despite efforts to assist foreigners in providing translated guidelines and forms, the lack of such widely distributed material was not comprehensive and resulted in ineffectiveness in the daily life of immigrants. Some prefectures, such as Oizumi (Figure 2), produced their materials to help the immigrants get vaccinated and prevent the contagion of COVID-19: 


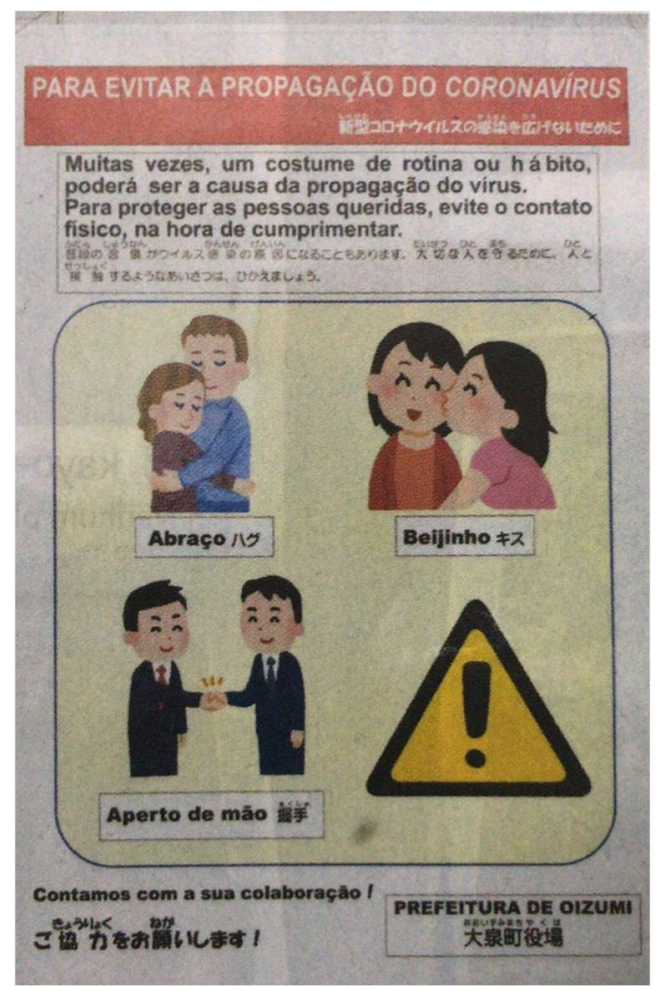

Figure 2. Oizumi Prefecture's Recommendations to Avoid the Dissemination of Coronavirus. Source: Fátima Kamata, Alternativa magazine.

That information published in the ethnic media joined the campaign in public spaces that the Prefecture of Oizumi and some Brazilian entities such as Maurício de Sousa Produções and The General Consulate of Brazil in Tokyo launched in the Portuguese language, as Figure 3 shows:

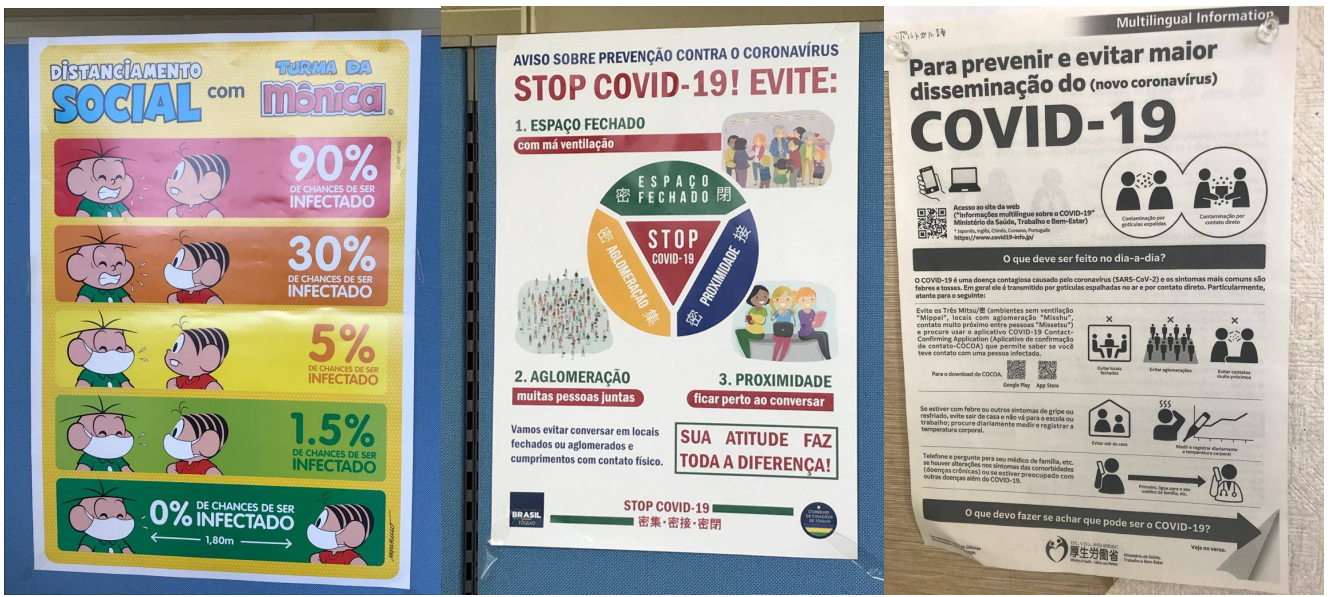

Figure 3. Oizumi Prefectures Public Awareness Campaign. Source: Authors' Archive.

If the process were more straightforward than it currently is, everything would be more accessible, even if dealing with forms in the Japanese language. One example that worked was the form created to receive JPY 100,000 as emergency aid offered by the Japanese government. It was a simple process. It was necessary to fill in a state with personal details and indicate a bank account where the government should make the deposit. Despite being in Japanese, it was a basic form and easy to fill out. All one had to do was fill it in, put it in the reply envelope that already had the recipient's address printed-the local government office, and take it to a post office. 
Considering the difficulty faced by some foreigners concerning the vaccine reservation process, it is fair to be concerned regarding the possibility that some people may have missed the deadlines or even given up on getting vaccinated. The ethnic press in Portuguese-such as the magazine Alternativa ${ }^{1}$ took a crucial role in publishing articles that helped keep the Brazilian immigrant population informed in their language. They also offered essential information in terms of where to find help for the different situations related to the pandemic, as Figure 4 shows:
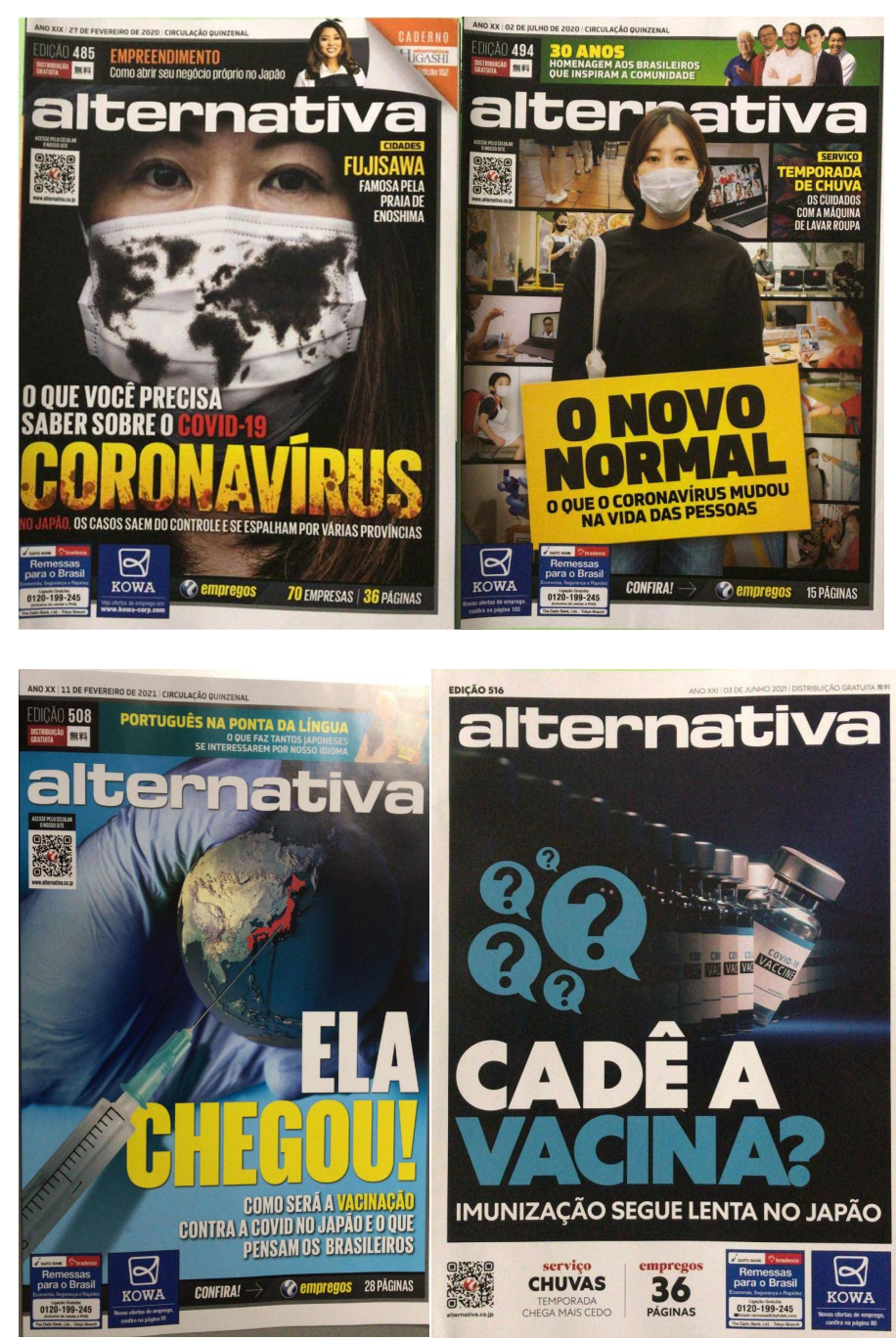

Figure 4. How the Ethnic Media Contributed to the Awareness of the Prevention of Coronavirus. Source: Authors' archive.

\subsection{Quarantine Controversies and the Daily Life of Japanese Brazilian Immigrants}

For a period of time, quarantine/social isolation has not been an effective and comprehensive action in Japan (Kamata 2020). Since Prime Minister Shinzo Abe's speech of the First State of Emergency in April 2020, the Japanese government resolved to neither demand nor impose measures to ensure that the population complied with a certain quarantine period, as was explicit in the Prime Minister's discourse (Cabinet Secretariat 2020). The government has been asking the population to collaborate to follow the guidelines regarding preventing contagion and avoidance of clusters (Kamata 2020). Thus, for many people, quarantine is not a rule or a government requirement but rather a request for collaboration. The onus, therefore, resides in the individual will rather than on the government's responsibility for public health. The explanation is that the basis for the government's posture is the Japanese Constitution. That information-released by the 
media - caused great concern and debates about preventing the spread of Coronavirus. For example, Fatima Kamata (2020) states: "The Constitution prevents Japan from adopting quarantine as is being done in some European countries and from resorting to punishment and imprisonment to enforce social isolation".

However, the justification that the imposition of quarantine contradicts rights guaranteed by the Constitution — such as freedom to circulate and public assembly—was contested in the article entitled "The coronavirus and Japan's Constitution", written by Lawrence Repeta (2020). In his analysis, the author states:

Civil libertarians may argue that an order to evacuate your home-or to stay inside-is an extreme limitation on constitutionally guaranteed rights such as freedom of movement, public assembly, and others. They would be correct. However, constitutional scholars such as professor Hajime Yamamoto of Keio University explain that those rights must be balanced against other constitutional provisions, especially Article 13, which stipulates that the "public welfare" is the highest consideration of all law and government action. There is no doubt that reasonable restrictions calculated to limit the spread of the coronavirus pass constitutional muster. (Repeta 2020)

As the attitude of Japanese leaders towards the pandemic drew international attention, some explanations based on Japanese culture and customs emerged. Repeta (2020) highlights some reasons regarding the fact that there is no mandatory quarantine in Japan:

We hear several possible explanations. One is that the Japanese people are so responsive to official requests they don't need such orders. Jishuku (selfregulation) really works. Another is that such orders are unnecessary because of Japan's extremely high standards of hygiene.

In addition, the habit of greeting people with just a bow has always been evident among the Japanese, especially when compared with greeting people with kisses, hugs, and handshakes, which is common among Brazilians, even among those in Japan. Without a doubt, avoiding physical contact is a very effective way to prevent contagion. One can already see how this reality is impacting customs in different parts of the world. However, these justifications based on Japanese culture and traditions have two contradictory interpretations. On the one hand, they are favorable characteristics. On the other hand, depending on the situation and how one chooses the words, they can also suggest an air of superiority - and even prejudice-against the culture and customs of other peoples residing in the country.

Whether constitutionally or culturally justifiable or not, the reality is that, so far, there has been no imposition of quarantine in Japan. Thus, since the pandemic's beginning rendered quarantine a "request" by the government, its effectiveness is doubtful. It means that, theoretically, people have the right to choose whether to quarantine or not. However, in practice, this right does not exist. Scholars have long analyzed how amidst Japanese society prevails the idea of the group's wellbeing and not the individual's. Therefore, according to the group's demands and government guidelines, the different sectors of society define what to do daily, resulting in divergent outcomes. Thus, it risks producing unnecessary contagions among the population.

For example, examining the education sector reveals that elementary schools have practically not had long periods of suspension from activities since the beginning of the pandemic. In February 2020, Prime Minister Shinzo Abe called for the closure of all schools as a preventive measure (Leussink 2020). According to data from the Ministry of Education, Culture, Sport, Science, and Technology of Japan, all schools were closed on 2 March 2020 (MEXT 2020a). On 7 April 2020, the national government declared a state of emergency nationwide (BBC 2020a). However, on 10 May 2020, 39 Prefectures revoked the state of emergency (Sugiyama 2020). That provoked that on 30 May 2020, the national government withdrew the state of emergency throughout the country (McCurry 2020). Thus, on 1 June 2020, 99\% of public schools reopened ((MEXT) 2020b). 
The temporary closure of schools evidenced different scenarios. For example, it required some teachers to go to students' homes to bring and check homework. It also made students attend schools on pre-established days and allocated time to submit assignments and pick up lessons. On the other hand, some schools seeking to continue their education with a low impact over children opted for a hybrid system, online and face-to-face. Nonetheless, the situation highlighted a more profound social reality. Despite having their activities suspended, some schools had to open their doors to receive some children. Because of parents' heavy workload-coupled with the lack of help from other people to take care of the children, schools have to receive those children who otherwise would be at home all day by themselves, unattended.

Although there are initiatives to reduce gender differences in the social and professional spheres, the Japanese social structure still does not offer women many options. Therefore, they double their roles as mothers and professionals working away from home. Despite the pandemic and numerous international news reporting the closing of schools in different countries, Japan is keen to keep schools open and preferably with face-to-face activities. In addition to efforts to guarantee the right to education, there may also be a significant concern related to the suspension of in-person classes and school activities on society in general, especially considering the reality of mothers who work outside the home. Babysitting and maid services are not yet standard in Japan. Usually, the wife is responsible for housework, child-rearing, and education. That, in turn, forces many women to quit their profession or occupation after marriage (Dias 2018, p. 29). Japanese Brazilian women living in Japan also suffer from that gender gap. Frequently, those who have children find it more difficult to find or keep a job.

Although highly praised, the Japanese education system widely lacks daycare centers or other similar services. The Ministry of Education has tackled the situation and has increased the number of centers in recent years. Nonetheless, a 2017 report visibilizes the difficulties that many mothers find to obtain a place in these establishments: "As of April this year, the number of children waiting to enroll for public daycare in authorized facilities was 26,081 across the country, caused by a lack of facilities and nursing staff" (Kyodo News 2017).

This reality motivates many Brazilian mothers to place their children in Brazilian schools and daycare centers (Dias 2017). In these establishments, the children can usually spend more time under the care of teachers and assistants who, besides caring for them, are also responsible for transporting them back and forth from home to the school or daycare center. For mothers who work and have no one to leave their children, these facilities add flexibility in their service hours. Yet, not many establishments are recognized by the Japanese Ministry of Education.

\section{Religious Discourses and Attitudes towards Self-Care}

The pandemic drastically changed everyone's routine and created a "new normal". However, that is especially true for religious organizations. As mentioned before, there has been no mandatory quarantine in Japan, but those arriving from abroad have to pass through quarantine. Concurrently, the government requested the collaboration of everyone to avoid agglomerations, which directly impacted the activities of churches and religious temples. The way religious organizations face reality has not been homogenous, and there are positive and negative situations.

On the positive side, many Christians churches, Buddhist temples, and Shinto shrines rapidly move to comply with the guidelines proposed by the Japanese government. For example, the local Roman Catholic churches accepted the order regarding the suspension of face-to-face Masses and events and sought alternative solutions such as online reflections (Vatican News 2020). That was particularly evident in the words of Mons. Tarcisio Isao Kikuchi (2021), Archbishop of Tokyo, in light of the Olympic games:

The Tokyo Olympic games which starts on 23 July and the Tokyo Paralympic games which starts on 24th August will be held in various places but mainly in 
the Tokyo Metropolitan area. With the declaration of a state of emergency, it is expected that the events will be held without spectators at venues especially in the Tokyo Metropolitan area. But at the same time, the gathering of the athletes and their support staff coming from all over the world raises concerns about causing further increase in number of coronavirus cases. For the past years, the Tokyo Archdiocese had originally been considering preparations so that each parish may be able to address the spiritual needs of the many people who would come to Japan for this international event. However, we have decided to cancel all plans and thus, will not take any special involvement in the Olympics and Paralympics. In addition, all those who will be coming to the Tokyo Metropolitan area during this period will be provided with information concerning the precautionary measures implemented against COVID-19 infection in the parishes and will be requested to refrain from visiting churches.

Nevertheless, as seen in news reports, some churches attended by Brazilians did not respect the guidelines and requests of the authorities, thus continuing to hold their ceremonies. On 14 January 2021, the government of Gunma Prefecture reported the finding of sixty positive cases of COVID-19 contagion at Belém Cristo Assemblies of God church in Ota City. The government requested that those among the 260 parishioners present in their activities came forward to be tested (Maeda 2021a). On 14 April 2021, Hideaki Omura - the governor of Aichi Prefecture-held a press conference to announce the appearance of 36 coronavirus cases at a church in the city of Toyota out of 130 attendees to the Easter Sunday service. The governor cataloged the event as "extremely pitiful" while emphasizing that "Singing and praying aloud can even be part of a religious event, but it is regrettable because we are in a time of coronavirus" (Maeda 2021b). Christianity is a minority in Japan (Córdova Quero 2007, 2008; Córdova Quero and Shoji 2014) and shares with New Religious movements a stigma of distrust and suspicion amidst Japanese society, a fact exacerbated during the pandemic (McLaughlin 2020). That is also true among the immigrants themselves.

Although impossible to generalize-as those cluster cases in churches attended by Brazilians are "isolated cases", there are some aspects to consider regarding religions professed by Brazilians in Japan. The situation complexifies due to the immigrants' residence because many attendees reside in other cities in the same prefecture or other prefectures. That situation and religious discourses impeded people from seeking self-care in light of God's supposed "divine power" to prevent contagion.

For many people — especially immigrants—religion and faith are sometimes the only sources of hope and strength to move forward amidst difficult times. However, it is crucial to reflect on alternative ways of professing the faith, considering the new reality of social distancing in light of the pandemic. That implies special attention not to put the faithful and other people at risk. Concerning the Brazilian immigrant communities, there is a strong criticism of evangelical churches mainly because they were the ones who made the news due to a large number of contagions. Following the pattern from Brazil, many immigrants generalize and refer to "the evangelical churches" as an umbrella term that differentiates from Roman Catholicism. In reality, evangelical or protestant churches also continue with face-to-face activities. All of them are supposed to be following the guidelines for preventing contagion; however, they have not.

In some situations-especially in the churches founded and attended by foreignersthe authorities cannot always effectively act because they need to work with prudence related to religious institutions. The situation originates because the Japanese constitution provides freedom of religion and requires the government to refrain from religious education or any other interference in religious activity (US Bureau of Democracy, Human Rights, and Labor 2018). Nonetheless, scholars have critiqued the ambivalence of the Japanese government regarding its relation to Shinto (Sumimoto 2000).

Although face-to-face activities continue to occur in some places, some religious leaders innovated by creating virtual celebrations (McLaughlin 2020). There is also the 
creation of projects such as studying biblical passages through short videos posted on YouTube, Facebook, and other platforms. In the case of essential celebrations such as baptisms or other sacraments, some churches carry out these activities with a small number of participants and a shorter celebration than usual. All those actions contribute to creating awareness among the immigrants regarding the need for care and prevention of spreading coronavirus. Religion is not an outdated or odd appendix to "irresponsible people", but a source for hope and strength amidst the pandemic.

\section{The Struggles of Immigrants: Hearing Their Concerns in Times of COVID-19}

\subsection{Concerns Related to Daily Life}

COVID-19 exposes people's fear of isolation and loneliness. Córdova Quero and Campos (2020) reflect on how many individuals become deeply involved with a profusion of access, e.g., social media, travel, latest technological devices, accumulation of social networks, etc. Many times, this leads to them avoiding even one hour of silence with themselves. In a sense, highly connected lives disallow them from immersing into the depths of who they are. The only way to do this is to balance introspection with relationality. Not many can live with themselves outside the internet or social media. In our present time, we have some of the most advanced communication systems in history, and we still fail to communicate with ourselves (Córdova Quero and Campos 2020).

Amidst that situation, Brazilian immigrants exert agency by coping with the pandemics and the limitations of language, culture, and the vicissitudes of COVID-19 the best they can. They resort to connectedness in meaningful ways or seek to empower their children and beloved ones with activities and gestures that bring forth hope and inspiration. There is no single recipe but creativity and the strength to ride the waves of Coronavirus to survive and thrive. This section presents four testimonies of immigrants who have weathered the situation in significant ways. The purpose of bringing them aims to highlight the resilience that immigrants possess vis-a-vis notions of hopelessness and passive attitudes stereotypically thrown over their shoulders.

Our first interviewee is Guilherme ${ }^{2}$, a 45-year-old university professor who has lived in Japan for the last twenty-seven years. Due to his profession, Guilherme can speak, read, and write Japanese fluently. When describing how his life has changed due to the outbreak of Coronavirus, he stated:

The COVID-19 pandemic had a significant impact on me as a researcher and a professor. First of all, it became impossible to make any research field trips, which was essential for most of my research. Not being able to travel also affected my stress since leaving Japan three times a year was a way for me to cope with the stress that living and working in Japan creates.

Guilherme also expressed his creativity in order to continue teaching amid the pandemic and the demand for virtual classes:

Besides that, I had to adapt to new ways of teaching, and it was very frustrating when having to give classes at the same time online and in the classroom. However, since the university allowed me to do it, I decided to give most of my classes in a hybrid form, in the classroom with some of the students while the remaining students attended the courses through Zoom. It was challenging, but it was the best way to cope with the pandemic, and my opinion of being against teaching only online. I didn't regret my decision because I confirmed that teaching in person, even using the new technologies, is much more effective than online. My biggest hope continues to be hoping for a time when I will go back to making my research field trips.

Guilherme breaks away from the stereotype that Brazilian immigrants only work in the industrial or service sectors of the Japanese labor economy. Highly skilled, he is part of the brain drain migration that affects Global South countries. His contributions to the academy parallel his commitment to foster education and knowledge to other immigrants in Japan. 
Yet, the presence of the pandemic profoundly challenges and impairs that commitment displayed over the last twenty-seven years.

Our second interviewee is Daise, a 47-year-old Brazilian woman and mother of two children who currently are 12 and 14 years old. She has been in Japan for over eighteen years, and can speak, read, and write Japanese. As a mother in Japan, she is also in charge of monitoring the education of her children. She expressed:

It has been sixteen months since the Novel Coronavirus started to affect children's lives in Japan directly. On 2 March 2021, Prime Minister Abe requested all schools to suspend classes, and it has resumed only three months later, on June 2. They were back to school but to a new normal. Children have to wear a mask all the time, even during physical activities, and keep social distance. Typical yearly activities such as sports, music, and art festivals, graduation ceremonies, and graduation trips are not happening or are very restricted.

Asked to express more about how the Coronavirus pandemic has affected their life as a family, Daise narrated:

School club activities [bukatsu] and Sports Lessons [naraigoto] are barely happening. The expression Corona butori ${ }^{3}$ is a trend in all conversation among parents, especially since children are experiencing weight gain due to the lack of exercise since the beginning of the pandemic. Children's social life out of school is essentially online. Playdates in the park were replaced by online games, decreasing physical activities even more. Their mental health is a concern as well. I believe that children need a routine, it grounds their life in a way that makes them feel safe, and all the insecurities and uncertainties caused by the pandemic bring a lot of anxiety. They cannot plan. As an example, my eldest son's graduation trip has already been postponed three times. They have no idea if they will have it soon or if they will have a proper graduation ceremony at all.

Although Daise could incarnate the stereotype that, as a mother, her primary task is to monitor her children's education, she manages to disrupt that mandate by encouraging her children to take more responsibility for their activities while remaining in full-time employment at her job. Nonetheless, the uncertainty of planning the future-such as her eldest son's graduation-adds stress to their life. Because she can communicate in Japanese, Daise endures many of those daily life hardships.

Our third interviewee is Paula, a 44-year-old Brazilian woman who has been in Japan for almost twenty-five years and speaks, reads, and writes Japanese at an advanced level. Due to her job, she constantly contacts the Brazilian immigrants in the Prefecture where she lives. She described the impact of the Coronavirus pandemic amidst the Brazilian community of immigrants in the following way:

Working directly with the Brazilian community in Japan, I followed the high volume of requests for financial aid, food, and essential hygiene items. That, combined with the vast fear surrounding our community during the COVID-19 pandemic, made me very worried because it became clear that most Brazilians are not in Japan to acquire a solid economic base. They live daily, spending the high monthly salaries earned after eighty or one hundred extra working hours. They do so at the expense of their mental and physical health while buying material goods that do not provide the possibility of gaining stable jobs or the facility to find a new job if necessary. To keep my position, I needed to seek remote solutions to maintain service and support for Brazilians. It was undoubtedly a time of growth and online discoveries that will influence future actions. They provide savings in resources, greater comfort for the organization and participants, and the chance to take information and assistance to people who are distant or unable to move. But it is necessary to admit that the "hiper-digitalization" of the services, events, and information disadvantages the elderly and those who use the internet as a simple entertainment tool. 
The lives of Paula and her family have been affected by the pandemic, especially concerning their economic well-being. In explaining the situation of her husband and other Brazilian immigrants, she stated:

At the beginning of the pandemic in Japan, the workload decreased a lot at the company where my husband works, and we had to save a lot until he was able to do extra work as a delivery boy for Uber Eats. This additional job was our salvation and how we managed to keep going without the decrease of our economies between June 2020 and April 2021. Insecurity about the future, the lack of perspective of returning to normal workload, and the fear of becoming ill impacted our lives permanently. Although feelings affected the hearts of virtually all of humanity during the pandemic, we knew that our situation was even more delicate. At least in Japan, foreigners are always the first to be dismissed when the companies lay off employees in times of economic crisis.

Paula highlights the reality of uneven economic relations between nationals and immigrants. Michael P. Todaro (1969) proposed a neoclassical economic explanation of migration as a by-product of "income differentials". Though there may be wage differentials between Brazil and Japan, many immigrants have educational backgrounds and training that go unrewarded in Japan. Their abilities or expertise often failed the commodification beyond the need for a labor force (Yamashiro and Quero 2012). One consequence is that the Brazilian immigrants take jobs refused by nationals and, in times of crisis or amid the actual pandemic, renders them as easily being dismissed from their jobs, as Paula expressed.

Our last interviewee featured in this section is Delmo, a 58-year-old Brazilian man who works at a factory. He has been in Japan for the last twenty-one years, but he does not speak Japanese. Neither does his wife. Due to this situation, he and his wife are facing many hardships. He described the irruption of the pandemic in the following way:

Facing a pandemic like this in a country where we don't speak the language and where we don't have extended family is very difficult. My family is my wife and my friends, but we don't even see friends anymore because of this pandemic. Everyone was terrified and avoided leaving the house. I think we all get into the home-work-home routine, other than that we go shopping or for some more significant need. It's sad to have to be isolated, and more tragic is to think that whoever takes COVID can't count on anyone's help because they have to be completely isolated. If it is severe, the person goes to a hospital. If it is a mild symptom, the person who lives is only home alone. If they live with their family, they go to a hotel indicated by the health agency not to contaminate other people in the house. But without knowing how to speak, read and write Japanese, everything is much more complex, so I avoid getting infected.

Delmo also described the situation in the work environment. There the interpersonal relations have changed due to the risk of contagion of Coronavirus. The distancing and isolation suffered at work coupled with the stress of those relatives and friends living in Brazil. Delmo expressed:

But without working, we cannot stay, and we end up at risk. The work environment has also changed a lot because people no longer have the same relationship with their colleagues. People are more distant. There is no longer that chat at lunchtime or during breaks. Now everyone is in their corner, for example, I don't stay in the cafeteria, I always have lunch alone in my car. In addition to all this, there is a concern for family and friends in Brazil, it is an unfortunate situation, and I miss them enormously. With the pandemic, it is difficult to travel to Brazil because of the risks and the quarantine rules to enter Japan, which is increasingly strict for foreigners, even if you are a permanent resident like me.

Delmo exemplifies one of the biggest fears among Brazilian immigrants: the possibility of fatalities occurring in Brazil while they are far away. Due to the pandemic, airports 
worldwide are either closed or operating at a minimum level. Traveling to Brazil from Japan is usually expensive, and during the Coronavirus pandemic became impossible due to the restrictions. Although one can reason about the motivations for that situation, in terms of immigrants' feelings, it is a source of added stress to the daily life adversities in Japan. Delmo evokes many common instances that other immigrants also fear.

Our four interviewees featured in this section are a small sample of the manifold situations that Brazilian immigrants have undergone during the COVID-19 pandemictheir words, feelings, and resilience point to the two simultaneous realities. On the one hand, the sense of calamity, discomfort, and fatigue prevails in their daily activities. That is something shared with other immigrant groups as well as Japanese nationals. On the other hand, their attitude and strength to face those circumstances also highlight the possibility of envisioning solutions and strategies deployed to survive in a foreign land. What underlines both realities is the daily lived experience to endure migratory experiences with all the concurrent conditions they entail. Although they may seem hopeless at times, their past experiences may have prepared them to confront the realities during the pandemic.

\subsection{Concerns Related to Faith and Religion}

In this section, we introduce three more of our interviewees who comment on their religious situations and concerns during the COVID-19 pandemic. They belong to two different religions: Christianity and Seicho-no-Ie, a religion of Japanese origin widespread among Japanese immigrants in Brazil, whose descendants who emigrated to Japan have continued to uphold as their spiritual practice.

A characteristic of all religious people in Japan is that when joining the local entities of their religions in Japan, they feel a cultural difference despite living the same faith (Córdova Quero and Shoji 2014). What happens is that an individual cannot live their faith outside a cultural environment, which affects the spiritual life of Brazilian immigrants in Japan in particular ways (Córdova Quero 2009, 2010, 2016; Dias 2018).

Our first interviewee in this section is Damaris, Brazilian, a 57-year-old woman who works in a factory. She has been in Japan for thirty-two years. Córdova Quero (2010, p. 48) asserted that many non-practicing Roman Catholics-when consulted about their spiritual life after migration-responded that they have "found" their faith in Japan. That is precisely the case of Damaris, as she expressed:

I was born in a Roman Catholic family, but I left the Christin church after coming to Japan, but not from religion. Here I live in the inaka [inlands], and there is no Roman Catholic church; at least, I never saw one, so I spent months and even years without going to a church. But with this pandemic, I approached the church again through social networks. Before, I even prayed once in a while, but only in times of stress. That is, in those situations that only God could help. But during this pandemic period, I started to listen to celebrations and reflections on biblical passages without realizing it. I cannot explain precisely how this happened, but I realized that the pandemic made me pay attention to religion in a different way, not just praying or mechanically listening to mass. I finally found faith again.

When asked about what changed in her religious experience before and during the pandemic, Damaris related the following:

Some friends started sending me links, and out of curiosity, I started to dedicate some time to listen to reflections, prayers, and even celebrations, but everything was very relaxed. Before, I had to go to a church to participate in these activities, which demanded long travel distances to the nearby parish, and spend money and time doing that. Now there are many options on Facebook, Youtube, and WhatsApp directly transmitted from Brazil. I can listen while cleaning the house or doing something else while even feeling at home in Brazil. Before, I had to go to church, but now it seems that the church comes to where I am, even if priests 
do not make the programs and events. That is very good because we don't have time for anything else with this busy kaisha [company] life.

One reality among Brazilian immigrants is that the Roman Catholic Church does not offer Mass in Portuguese in all of its parishes. Only a few of them have access to one of the Brazilian priests-missionaries-who can say Mass in that language. On the other hand, the parishes which offer Mass in Portuguese do not happen every Sunday but once a month. Therefore, the days and times of the Mass schedule vary from parish to parish. In addition, the distances that immigrants have to cover to reach the parish can be up to four or five hours by car. In other words, a person or family who decides to attend a monthly mass in Portuguese must have up to ten hours of travel time to and from the parish, plus the time of the Mass and the social time after it. In other words, a full day must be available, which is not always possible due to work schedules or the need to work overtime on weekends to cover the monthly expenses (Córdova Quero 2007).

Damaris relates that traveling to the parish for Mass in Portuguese is a reality for Brazilian immigrants that their Japanese counterparts do not necessarily experience. Therefore, the advantage of having virtual ceremonies helps the immigrants to maintain their spiritual life without spending significant amounts of money and travel time to do it in a face-to-face Mass. However, the reality then is that people are increasingly looking for only transmitted resources. While some resources include reflections, other activities feature music, prayers, and explanations of biblical passages. Some of these activities originate in Brazil, while others are from Japan. Many Brazilian lay and missionary individuals who work in Roman Catholic parishes in Japan produce online content to serve the Brazilian immigrant community. Yet, it is noteworthy that worldwide, the Roman Catholic Church has not allowed a virtual Eucharist as the Protestant, Anglican, and Independent Catholic Churches have done (Córdova Quero and Campos 2020). On the one hand, that enable them to continue maintaining their faith life in their language, but, on the other hand, it distances them from the Brazilian immigrant community by offering them "a taste" of their country of origin.

Our second interviewee is Sister Thaís, a 53-year-old nun who has been a missionary to Japan for almost 30 years. Born in Europe, she has dedicated her life's mission to serve not only the Brazilian immigrants in Japan but also other immigrant communities and the Japanese youth since practically the inception of the dekassegui movement. Sister Thaís knows the reality of immigrants in detail because of her full-time dedication to visiting individuals, families, and communities in different prefectures of Japan.

Similar to many European, Asian, North American, or Latin American missionaries serving the diverse communities of immigrants in Japan within the Roman Catholic Church, Sister Thaís travels permanently — and for many hours - to participate in the activities that compose her pastoral work. For her and many Roman Catholic women, the Roman Catholic Church is an institutional nexus among the robust social networks already present amidst Brazilian immigrants. These networks are essential in every aspect of their survival within the context of Japanese society. As soon as one walks into a church or social gathering of Brazilian immigrants, one can observe the new networks' (re)configuration. Those networks were severely affected by the COVID-19 pandemic. With the weakening of the face-to-face interactions and the closing of parishes for Masses and other activities, many Brazilian immigrants endured the hardships by themselves, as detailed by Sister Thaís:

From what I know about Brazilian immigrants' spiritual life in Japan, the pandemic affected their participation, the churches, and the masses. In the first place, the church canceled the masses for a long time. I have witnessed that the situation in Brazil also turned out to be very serious and that many immigrants lost family members due to COVID-19. They had a challenging and worrying time when they didn't have news of their relatives or missed them because of their death. Most of them could not even attend the funeral because it was impossible to travel at the beginning of the pandemic. On the other hand, since the pandemic, Masses in Japan have been held irregularly. At times, they were allowed, to then 
prohibited, and later they were allowed with a limited number of participants. Even when it was possible to hold in-person Masses, we noticed far fewer people attending than regular times. I think this is because people are afraid of catching COVID-19 and being out of work. That means not going to work and not being seen at work because of being sick at home or in the hospital. In addition to this, treatment is not cheap, and many people find themselves struggling financially. I believe that these two aspects- the issue of contagion and the economic environment on one side, and the spiritual issue, on the other-were circumstances that made life difficult for the Brazilian people in Japan.

The relationship between spiritual life and economic or family situations is not so disconnected or out of place because they traverse people. As we have previously stated, the different roles of religious institutions in the lives of Brazilian immigrants are not limited to the spiritual but promote the integral wellbeing of the people. What happens to them economically or in their health impacts their faith, and vice versa. As a place of socialization and spiritual growth, the Roman Catholic Church becomes an important place in the lives of people who practice this spiritual path. That is why it is so important to note how people have creatively addressed this need through the media and social media. Sister Thaís lists the following activities:

The way Brazilian immigrants found to maintain and nourish their faith during this pandemic was through the internet. That was not only to attend Mass virtually but also to organize among themselves to pray the rosary at some point during the week, set aside times of prayer together, and share daily life situations. At the same time, they have also been able to access a multiplicity of conferences, workshops, and sermons on YouTube. They even access the recorded messages that I also send to the communities as a missionary. All these situations have created resources that maintained their faith and nourished their hope amidst this crisis. However, from October [2021] onwards, it seems that the Masses are going to be in person again, so I am hopeful that people will return to the parishes and begin to have less fear and more courage to return to the Church to find the strength they need to overcome such a difficult situation for everyone as the COVID-19 pandemic.

The words of Sister Thaís reveal once again how COVID-19 has forced believers around the world to look for viable alternatives for the long-term care of their spiritual lives. Brazilian immigrants share this with other believers, whether in Japan, Brazil, or other parts of the world. Virtual lectures, meditations, prayers, phone counseling, or online Masses were possible before the pandemic. However, in the current world, it is profoundly challenging for believers and institutions to continue living their faith in the same way as before COVID-19. Strictly speaking, being physically present in the same space may not be the traditional way from now on. These days, believers experience their spiritual practices through technology. When they use Zoom or Facetime, they not only honor shared time, but also their well-being, the news about their families, and their loved ones. They become a spiritual community again among the larger immigrant group of which they are part.

By naming the many strategies through which Brazilian immigrants keep their faith alive, Sister Thaís also responds to the recognition of the needs of the people beyond the material issues. Using the theological terms, we could infer that the many virtual gatherings constitute a sacrament for those on the other side of the screen who sit alone at home, with a rosary or a Bible. For Christians, the sharing of wine and bread is called the "eucharist". The Greek word behind the term is eukaristos, which means "give thanks". In Sister Thaís' expressions, we come to acknowledge the many "thanksgivings" amidst the lives of Brazilian immigrants in Japan: their lives, their ability to connect even across the limits of distance, and their resilience to endure together the current crisis affecting all humanity. 
Our last interviewee is Márcia, a 59-year-old Brazilian woman who has been in Japan for thirty-five years, but returned a few times to Brazil when she was younger. Márcia practices the Japanese religion called Seicho-no-Ie (House of Growth), a monotheistic religion founded on 1 March 1935, by Rev. Masaharu Taniguchi. Although initially related to the ceremonies of Shintoism, Seicho-no-ie practices ancestor worship and the ceremony of purification of the mind (Clarke 1999). Its other three practices are the evocation of the Jissô (true image), that is, the real essence of all people and Shinsokan meditation, prayerful meditation revealed directly to Rev. Taniguchi when he attained spiritual enlightenment, and finally, the prayer for the manifestation of the "Human Form" (Carpenter and Roof 1995). Seicho-no-Ie offers these practices in the institution's weekly meetings, conferences, training events at the religious academies, and ceremonies held on Sundays. Some of these practices, especially Shinsokan meditation, are also performed privately and daily by individuals (De Paiva 2005).

Although Márcia's experience is in a different religion than Christianity, the situations she described are similar to those experienced by many Christians. At the same time, it shows how the cultural context-namely, Brazil and Japan-is different. In the interview, Márcia told us the following:

Here in Japan, I have been actively participating in Seicho-no-Ie for more than ten years. I have always loved it, but with the pandemic, everything has changed. In the past, we had meetings, events, and everything was very lively. We went to people's houses to pray, but now people don't do that anymore. With the pandemic, everything went online. For me, what changed is that now I attend the meetings in Brazil through Facebook. I like it very much because the meetings there are very well prepared. Besides, the speakers in Brazil are very different. I feel that they show affection; they speak from their hearts. Here in Japan, we also have virtual meetings, but it is very different. I think that people here are already very "Japanese"; they don't express their feelings. I am feeling a massive difference between the virtual meetings in Brazil and the ones here. That is very strange because I have known people here for so long, but I feel more at ease with the people from Brazil. I feel freer to talk and ask, and feel more welcome. Because of the pandemic, the staff is not doing many study sessions as it has canceled the face-to-face meetings. They have done many debates, and it gets a very rare atmosphere. I am terrified, and I feel a little embarrassed to speak in front of them. But the worst thing is that here in Japan everybody is very busy, so when we need advice or call to ask something or talk, we realize that some of the preachers or coordinators don't always have time to pay attention to us, which is very bad.

One of the significant issues during the pandemic for many adults is the use of social media and communication applications. While young people have had no trouble adapting to a digital format, those who have lived their lives dependent on face-to-face encounters and print readings have had to adapt quickly to technology. Most of the time, there has been no instruction or sensitivity on the part of religious organizations in Japan to help older people make this transition, something that has happened in Brazil and other Latin American countries. For example, Córdova Quero and Campos (2020) describe how some Christian churches wrote their materials to help with this issue. However, Márcia tells us about the difficulty of the elderly and their efforts to help them overcome this situation amid the Seicho-no-Ie immigrant community:

With the pandemic, everything got worse because the older people have difficulty using Facebook or Zoom, and the coordinators don't always correctly explain how we should access the meetings. I think the whole shift was not very good because many people have difficulty using the apps. It seems that only those who have more knowledge participate, and some of us are a little unable to participate. I try to help people who call me asking how to do it, but sometimes 
even I can't log in. I don't know what happens because the lecturer in my city in Brazil, always sends me the link and I can enter correctly, but the one here often left me with a problem. With this pandemic, many people ask me for prayers; everybody requires prayers, but I think this online thing is not working very well because many people need special attention and don't have it. So, in my case, what changed the most is that I started to participate in the online activities of Seicho-no-Ie in Brasil because I think that the people there show the feelings from the bottom of their hearts. However, I heart for the older adults who have no one to help them and become strange to their communities due to technology issues.

Márcia managed to enunciate one of the most salient points of the needs of people in any faith: connection to a supportive community. Spirituality involves the practices of faith and that sense of belonging and group that affirms each person's place within that religion. That is also a call to religious leaders to strengthen as we continue to navigate the COVID-19 pandemic.

Listening to the needs of Brazilian immigrants in Japan, we recognize that the spiritual practices of the different faiths they profess can still happen in virtual space. Especially in light of the COVID-19 pandemic, face-to-face religious rituals and faith practices seem to become more and more a question of privilege in the future. The reasons are not only related to the pandemics but also economical and technology issues. Amid that new situation, Brazilian immigrants continue to foster niches for keeping their faith and spiritual life healthy against all odds.

\section{Conclusions}

Our analysis has highlighted the concerns of Brazilians in Japan amidst the COVID-19 pandemic. Those concerns extend beyond the usual hardships of the language barrier or cultural differences. Even those who speak the Japanese language and have been in the country for many years suffer and find themselves lost when facing certain situations such as access to medical treatment or vaccination against COVID-19. For many, the pandemic heightened the feeling of loneliness, longing, and concern for loved ones who were far away. It also made evident the inability or impossibility of carrying out activities that were previously part of the routine. For many immigrants, the pandemics stressed their desire and need for welcoming without prejudices, especially when one becomes fragile due to the instability of the situation.

The reality caused by COVID-19 shows that doubts, dissatisfaction, financial difficulties, insecurity, and uncertainties regarding the future do not constitute difficulties based on ethnicity, gender, or social class. On the contrary, they are aspects of reality that impact every individual and community in different countries worldwide. However, it is crucial to consider those aspects more closely when they weigh in the lives of immigrants. By doing so, we ascertain that socioeconomic conditions and different levels of understanding and adaptation to the dynamics of the host society enhance the difficulties in moments of emergency, especially in light of the current pandemic. In addition, it is clear that combined with knowledge of the local language, immigrants' culture of origin, customs, and religious practices directly interfere in their decision making in times of distress. Each country must take responsibility for the immigrants it receives who-along with their descendants-often constitute the labor force supporting the secondary sectors of the labor market. Whether immigrants or not, each of us must be aware of the importance and need to develop our empathy and respect for each other with all the diversity it entails. Exploring the situations of Brazilian immigrants may provide further insights that could benefit those who are far from their place of origin and those who witness their daily lived experiences.

Among all these situations, the spiritual question is essential and should not be invisible or left aside in the analysis of the life and experience of Brazilian immigrants in Japan. The situations listed in this research are not the only ones they negatively experienced in Japan during this pandemic. However, they give us an idea of how important it is to 
consider all aspects of daily life while also recognizing the religious diversity currently present in the country. On the other hand, they speak of the need to acknowledge that Japanese society, whether among nationals or foreigners, is not ethnically, culturally, or religiously homogeneous. People's expectations about faith and religious institutions both within the family and amid Japanese society or within religious institutions such as the Roman Catholic Church, the Evangelical Churches, or other religions undoubtedly impact the self-understanding of Brazilian immigrants. However, this is only half of the picture; the other half lies in the possibilities of self-determination and agency that these immigrants can exercise in Japanese society. As shown in the interviews, the agency and creativity of people in dealing with the COVID-19 pandemic have been remarkable. However, it is essential to note that people have also suffered loss, loneliness, and stress. However, virtuality has helped to connect people and give them possibilities for spiritual enrichment and accompaniment.

Author Contributions: All works have done by the two authors together. All authors have read and agreed to the published version of the manuscript.

Funding: This research received no external funding.

Institutional Review Board Statement: Not applicable.

Informed Consent Statement: Informed consent was obtained from all subjects involved in the study.

Data Availability Statement: Not applicable.

Conflicts of Interest: The authors declare no conflict of interest.

\section{Notes}

1 Alternativa magazine was launched on 24 May 2001, and has completed twenty years of services to the Brazilian community in Japan. In addition to the printed version-of free distribution, readers can find it on the internet as Alternativa Online (https: / / www.alternativa.co.jp/) (accessed on 31 July 2021).

2 Pseudonyms replaced real names in this secton to protect the anonymity and privacy of our interviewees.

3 The expression Corona butori [コロナ太り] conveys the idea of people gaining weight due to staying at home all day in light of the Coronavirus pandemic.

\section{References}

Agência France Presse. 2020. Três japoneses retirados de Wuhan estão infectados com novo coronavírus. Correio Braziliense, January 30. Available online: https://www.correiobraziliense.com.br/app/noticia/mundo/2020/01/30/interna_mundo,824405/tresjaponeses-retirados-de-wuhan-estao-infectados-novo-coronavirus.shtml (accessed on 31 July 2021).

Akiyama, Shinichi. 2020. Japan Finishes Distributing 'Abenomasks' to all Households after 2 Months. The Mainichi Shimbum, June 26. Available online: https:/ / mainichi.jp/english/articles/20200626/p2a/00m/0na/002000c (accessed on 31 July 2021).

BBC. 2020a. Coronavirus: Japan Declares Nationwide State of Emergency. BBC News, April 16. Available online: https:/ /www.bbc. com/news/world-asia-52313807 (accessed on 31 July 2021).

BBC. 2020b. Yoshihide Suga Elected Japan's New Prime Minister Succeeding Shinzo Abe. BBC News, September 16. Available online: https://www.bbc.com/news/world-asia-54172461 (accessed on 31 July 2021).

Busetto, Arielle. 2020. Japan's \$1000 Coronavirus Cash Handout to Citizens: What You Need to Know. Japan Forward, April 17. Available online: https:/ /japan-forward.com/japans-1000-coronavirus-cash-handout-to-citizens-what-you-need-to-know / (accessed on 31 July 2021).

Cabinet Secretariat. 2020. [COVID-19] Press Conference by the Prime Minister Regarding the Declaration of a State of Emergency. April 7. Available online: https://japan.kantei.go.jp/98_abe/statement/202004/_00001.html (accessed on 31 July 2021).

Carpenter, Robert T., and Wade Clark Roof. 1995. The Transplanting of Seicho-no-Ie From Japan to Brazil: Moving Beyond the Ethnic Enclave. Journal of Contemporary Religion 10: 41-54. [CrossRef]

Clarke, Peter B. 1999. Japanese New Religious Movements in Brazil: From Ethnic to 'Universal' Religions. In New Religious Movements: Challenge and Response. Edited by Bryan Wilson and Jamie Cresswell. London: Routledge, pp. 197-210.

Consulado Geral do Japão em São Paulo. 2021. Comunicado Sobre as Medidas do Governo do Japão e Solicitações de Visto Relacionadas à Infecção pelo novo Coronavírus. March 22. Available online: https://www.sp.br.emb-japan.go.jp/itpr_pt/not_21 _03_coronavirus99.html (accessed on 31 July 2021). 
Córdova Quero, Hugo, and Michael S. Campos. 2020. Transgressing Quarantine: Queering, Theologizing, and Traversing Virtual and Real Bodies. Santiago de Chile and Bogotá: GEMRIP Ediciones/IADLA Ediciones.

Córdova Quero, Hugo, and Rafael Shoji. 2014. Introduction: On Transnational Faiths and Their Faithfuls. In Transnational Faiths: Latin-American Immigrants and Their Religions in Japan. Edited by Hugo Córdova Quero and Rafael Shoji. Aldershot: Ashgate, pp. 1-31.

Córdova Quero, Hugo, Melanie Perroud, Alberto Fonseca Sakai, and Jane H. Yamashiro. 2008. Deconstructing Nikkei: Politics of Representation among People of Japanese Ancestry Migrating from the Americas to Japan. Migrations and Identities 1: 115-31.

Córdova Quero, Hugo. 2007. Worshiping in (Un)Familiar Land: Brazilian Migrants and Religion in Japan. Encontros Lusofonos 9: 25-37.

Córdova Quero, Hugo. 2008. Encounter Between Worlds: Faith and Gender among Brazilian Migrants in Japan. The Journal of Sophia Asian Studies 26: 57-74.

Córdova Quero, Hugo. 2009. Promised Land(s)? Ethnicity, Cultural Identity, and Transnational Migration among Japanese Brazilian Workers in Japan. Iberoamericana 31: 19-33.

Córdova Quero, Hugo. 2010. Faithing Japan: Japanese Brazilian Migrants and the Roman Catholic Church. In Gender, Religion and Migration: Pathways of Integration. Edited by Glenda Tibe Bonifacio and Vivienne S. M. Angeles. Lanham: Lexington Books, pp. 37-54.

Córdova Quero, Hugo. 2013. Del discurso a la praxis pastoral. Dilema de la Iglesia Católica Romana en Japón frente a los inmigrantes japoneses brasileños. Anatéllei 15: 39-56.

Córdova Quero, Hugo. 2014. Made in Brazil? Sexuality, Intimacy, and Identity Formation among Japanese Brazilian Queer Immigrants in Japan. In Queering Migrations Towards, From, and Beyond Asia. Edited by Hugo Córdova Quero, Joseph N. Goh and Michael Sepidoza Campos. New York: Palgrave MacMillan, pp. 41-59.

Córdova Quero, Hugo. 2016. Embodied (Dis)Placements: The Intersections of Gender, Sexuality, and Religion in Migration Studies. In Intersections of Religion and Migration: Issues at the Global Crossroads. Edited by Elena Fiddian-Qasmiyeh, Jennifer B. Saunders and Susanna Snyder. Religion and Global Migrations series \#1. New York: Palgrave MacMillan, pp. 151-71.

De Carvalho, Daniela. 2003. Migrants and Identity in Japan and Brazil: The Nikkeijin. London: Routledge Curzon.

De Paiva, Geraldo José. 2005. Novas religiões japonesas e sua inserção no Brasil: Discussões a partir da psicologia. Revista USP 67: 208-17. [CrossRef]

Dias, Nilta. 2015. Dekasseguês: Um português diferente? Variações linguísticas e interculturalidade nas migrações contemporâneas dentro do sistema-mundo moderno. Horizontes Decoloniales 1: 62-101.

Dias, Nilta. 2017. Crianças e jovens brasileiros no Japão: Educação, cultura e inquietudes. Quaestio: Revista de Estudos em Educação 19: 607-29. [CrossRef]

Dias, Nilta. 2018. «Não há lugar para mim na casa de Deus?»: Identidade e espiritualidade de lésbicas brasileiras na região de Kanto, Japão. Conexión Queer: Revista Latinoamericana y Caribeña de Teologías Queer 1: 15-48.

Higuchi, Naoto, and Kiyoto Tanno. 2003. What's Driving Brazil-Japan Migration? The Making and Remaking of the Brazilian Niche in Japan. International Journal of Japanese Sociology 12: 33-47. [CrossRef]

Hirschman, Charles. 2004. The Role of Religion in the Origins and Adaptations of Immigrant Groups. The International Migration Review 38: 1206-33. [CrossRef]

Kamata, Fatima. 2020. Como a resposta ao coronavírus está derrubando a popularidade do primeiro-ministro do Japão. BBC News Brasil, April 17. Available online: https:/ / www.bbc.com/portuguese/internacional-52304842 (accessed on 31 July 2021).

Kawaguchi, Kaoru. 2007. Toward a Multi-Cultural Church Community. The Japan Mission Journal 61: 93-100.

Kiko, Hachima. 2021. Ibaraki Health Center Warns People not to Eat with Foreigners to Prevent Spreading COVID. Japan Today, May 23. Available online: https:/ /japantoday.com/category/national/Ibaraki-health-center-warns-people-not-to-eat-with-foreignersto-prevent-spreading-COVID (accessed on 31 July 2021).

Kikuchi, Tarcisio Isao. 2021. Olympics, Churches Closed to Athletes to Stop Covid Contagion. AsiaNews.it, July 12. Available online: http:/ / www.asianews.it/news-en/Olympics,-churches-closed-to-athletes-to-stop-Covid-contagion-53622.html (accessed on 31 July 2021).

Kyodo News. 2017. Babysitters in Great Demand Amid Daycare Shortage in Japan. November 20. Available online: https:/ / english.kyodonews.net/news/2017/11/e30d7048e1f7-babysitters-in-great-demand-amid-daycare-shortage-injapan.html?phrase $=$ north $\% 20$ korea\&words $=($ accessed on 31 July 2021).

Kyodo News. 2020. Gov't Sued over Disclosure of 'Abenomask' Unit Price, order Numbers. September $28 . \quad$ Available online: https:/ / english.kyodonews.net/news / 2020/09/2f22e10b0943-govt-sued-over-disclosure-of-abenomask-unit-price-ordernumbers.html (accessed on 31 July 2021).

Kyodo News. 2021. Tokyo Hotel Rapped for 'Japanese only' Notice for Elevator Use. July 11. Available online: https://english. kyodonews.net/news/2021/07/aa2015e76a9e-tokyo-hotel-rapped-for-japanese-only-notice-for-elevator-use.html (accessed on 31 July 2021).

Kyodo Staff Reporter. 2020. Japan Confirms First Case of Coronavirus that has Infected Dozens in China. The Japan Times, January 16. Available online: https://www.japantimes.co.jp/news/2020/01/16/national/science-health/japan-first-coronavirus-case/ (accessed on 31 July 2021).

Leussink, Daniel. 2020. PM Abe Asks all of Japan Schools to Close over Coronavirus. Reuters, February 27. Available online: https:/ / www.reuters.com/article/us-china-health-japan-idUSKCN20L0BI (accessed on 31 July 2021). 
Linger, Daniel Touro. 2001. No One Home: Brazilian Selves Remade in Japan. Stanford: Stanford University Press.

Maeda, Masamichi. 2021a. Gunma relata 60 casos de coronavírus em igreja da Assembleia de Deus. Alternativa, January 14, p. 519. Available online: https:/ / www.alternativa.co.jp/Noticia/View/88603/Gunma-relata-60-casos-de-coronavirus-em-igreja-daAssembleia-de-Deus (accessed on 31 July 2021).

Maeda, Masamichi. 2021b. Aichi quer proibir uso de igreja em Toyota após 36 casos de Covid no local. Alternativa, April 14, p. 523 Available online: https: / www.alternativa.co.jp/Noticia/View / 89470/Aichi-quer-proibir-uso-de-igreja-em-Toyota-apos-36 -casos-de-Covid-no-local (accessed on 31 July 2021).

Matsue, Regina. 2003. Overseas Japanese New Religion: The Expansion of Sekai Kyuseikyo in Brazil and Australia. Yakara: Studies in Ethnology 33: 20-34.

Matsue, Regina. 2006. Religious Activities Among the Japanese-Brazilians 'Dual Diaspora' in Japan. In Religious Pluralism in the Diaspora. Edited by P. Pratap Kumar. International Studies in Religion and Society \#4. Leiden: Brill, pp. 121-46.

Matsuoka, Hideaki. 2004. Burajirujin to Nihon Shyukyo Sekai Kyuseikyo no Fukyo to Jyuyo [Brazilians and a Japanese New Religion]. Tokyo: Kobundo.

Matsuoka, Hideaki. 2007. Japanese Prayer Below the Equator: How Brazilians Believe in the Church of World Messianity. Lanham: Lexington Books.

McCurry, Justin. 2020. Japan Lifts State of Emergency after Fall in Coronavirus Cases. The Guardian, May 25. Available online: https:/ / www.theguardian.com/world/2020/may/25/japan-lifts-state-of-emergency-after-fall-in-coronavirus-cases (accessed on 31 July 2021).

McLaughlin, Levi. 2020. Japanese Religious Responses to COVID-19: A Preliminary Report. Japan Focus: The Asia-Pacific Journal 18: 1-22. Available online: https:/ / apjjf.org/2020/9/McLaughlin.html (accessed on 31 July 2021).

Ministry of Education, Culture, Sport, Science, and Technology of Japan (MEXT). 2020a. Information on MEXT's Measures against COVID-19. Available online: https:/ / www.mext.go.jp/en/mext_00006.html (accessed on 31 July 2021).

Ministry of Education, Culture, Sport, Science, and Technology of Japan (MEXT). 2020b. Os Esforços Feitos Para Garantir o Aprendizado nas Escolas Japonesas Devido ao Novo Coronavírus. Available online: https:/ /www.mext.go.jp/a_menu/coronavirus/1411020_ 00004.html (accessed on 31 July 2021).

Ministry of Foreign Affairs of Japan. 2021. Border Enforcement Measures to Prevent the Spread of Novel Coronavirus (COVID-19). August 2. Available online: https:/ / www.mofa.go.jp/ca/fna/page4e_001053.html (accessed on 31 July 2021).

Ministry of Justice of Japan. 2007. Zairyuu Gaikokujin Toukei (Statistics of Foreign Residents). Tokyo: Japan Immigration Association. (In Japanese)

Ministry of Justice of Japan. 2015. Zairyuu Gaikokujin Toukei (Statistics of Foreign Residents). Tokyo: Japan Immigration Association. (In Japanese)

Ministry of Justice of Japan. 2020. Zairyuu Gaikokujin Toukei (Statistics of Foreign Residents). Tokyo: Japan Immigration Association. (In Japanese)

Ministry of Land, Infrastructure, Transport and Tourism of Japan. 2020. Summary of The White Paper on Land, Infrastructure, Transport and Tourism in Japan, 2020. Tokyo: Policy Bureau, MLITTJ.

Mullins, Mark. 2006. Between Inculturation and Globalization: The Situation of Roman Catholicism in Contemporary Japan. Paper presented at the Annual Conference of the American Academy of Religion, Washington, DC, USA, November 18-21.

Nussbaum, Martha C. 1997. Constructing Love, Desire, and Care. In Sex, Preference, and Family: Essays on Law and Nature. Edited by David M. Estlund and Martha C. Nussbaum. Oxford: Oxford University Press, pp. 17-43.

Osaki, Tomohiro. 2020. Abenomask? Prime Minister's 'two Masks per Household' Policy Spawns Memes on Social Media. The Japan Times, April 2. Available online: https://www.japantimes.co.jp/news/2020/04/02/national/abe-two-masks-social-media/ (accessed on 31 July 2021).

Osumi, Magdalena. 2020. Naha goes on high alert, days after visit by virus-hit cruise ship. The Japan Times, February 5. Available online: https://www.japantimes.co.jp/news/2020/02/05/national/science-health/naha-alert-coronavirus-last-weekquarantine-cruise-ship/ (accessed on 31 July 2021).

Pasteur de Faria, Louise Scoz. 2020. Doing Research in a Pandemic: Shared Experiences from the Fieldwork. Halo Ethnographic Bureau, May 6. Available online: https:/ / medium.com/halobureau/doing-research-in-a-pandemic-shared-experiences-fromthe-fieldwork-fa1a00fc86fc (accessed on 31 July 2021).

Pye, Michael. 2011. Distância cultural na transplantação de religiões japonesas em países distantes. REVER 11: 11-31. [CrossRef]

Radford Ruether, Rosemary. 1993. Sexism and God-Talk: Toward a Feminist Theology. Boston: Beacon Press.

Repeta, Lawrence. 2020. The coronavirus and Japan's Constitution. The Japan Times, April 14. Available online: https://www. japantimes.co.jp/opinion/2020/04/14/commentary/japan-commentary/coronavirus-japans-constitution/ (accessed on 31 July 2021).

Reuters. 2020. Health Minister Apologizes after 23 Passengers Let off Diamond Princess without Additional Coronavirus Tests. The Japan Times, February 22. Available online: https://www.japantimes.co.jp/news/2020/02/22/national/coronavirus-chibakumamoto/ (accessed on 31 July 2021).

Roth, Joshua Hotaka. 2002. Brokered Homeland: Japanese Brazilian Migrants in Japan. Ithaca: Cornell University Press. 
Sato, Miko, Ichiro Itoda, Hirokazu Kimura, Naoki Onizuka, Seiichi Ichikawa, Hiroshi Hasegawa, Masahiro Matsuo, Yosuke Terao, and Ken Hasimoto. 2001. "Tokyochiiki ni Okeru HIV/STD Kansen Yobou no Suishin ni Kansuru Kenkyu" [Research on the Promotions for Prevention of HIV/STD Infection in Tokyo]. In HIV Kansensho no Doukou to Yoboukainyu ni Kansuru Shakai-EkigakuTeki Kenkyu [Annual Report of the Study Group on Socioepidemiological Studies on Monitoring and Prevention of HIV/AIDS]. Edited by Kihara Masahiro. Tokyo: Ministry of Health, Labor and Welfare, pp. 122-5.

Sayuri, Juliana. 2020. Missionários dekasseguis: Como imigrantes brasileiros espalham o Evangelho no Japão. UOL Brasil, September 23. Available online: https:/ / noticias.uol.com.br/ultimas-noticias/bbc/2020/09/23/missionarios-dekasseguis-como-os-imigrantesbrasileiros-espalham-o-evangelho-no-japao.htm (accessed on 31 July 2021).

Sayuri, Juliana. 2021. Consulado no Japão recebe cartas contra brasileiros em cidade foco de covid. UOL Brasil, July 15. Available online: https:/ / www.uol.com.br/esporte/olimpiadas/ultimas-noticias/2021/07/15/japoneses-protestam-contra-brasileirosem-cidade-com-foco-de-covid-19.htm?cmpid=copiaecola (accessed on 31 July 2021).

Schüssler Fiorenza, Elizabeth. 1994. In Memory of Her: A Feminist Theological Reconstruction of Christian Origins. New York: Crossroads.

Shimada, Gaku. 2020. A Legacy Slipping Away: Why Shinzo Abe Stepped Down. Nikkei Asia, August 30. Available online: https:/ / asia.nikkei.com/Politics/Inside-Japanese-politics/A-legacy-slipping-away-Why-Shinzo-Abe-stepped-down (accessed on 31 July 2021).

Sugiyama, Satoshi. 2020. Japan to Lift Coronavirus State of Emergency in 39 Prefectures: The Nation's Capital and Seven Prefectures will Maintain Emergency Measures for Now. The Japan Times, May 14. Available online: https://www.japantimes.co.jp/news/20 20/05/14/national/japan-coronavirus-emergency-39-prefectures / (accessed on 31 July 2021).

Sumimoto, Tokihisa. 2000. Religious Freedom Problems in Japan: Background and Current Prospects. The International Journal of Peace Studies. 5. Available online: https://www.gmu.edu/programs/icar/ijps/vol5_2/sumimoto.htm (accessed on 31 July 2021).

Suppasri, Anawat, Miwako Kitamura, Haruka Tsukuda, Sebastien P. Boret, Gianluca Pescaroli, Yasuaki Onoda, Fumihiko Imamura, David Alexander, Natt Leelawat, and Syamsidike. 2020. Perceptions of the COVID-19 pandemic in Japan with respect to cultural, information, disaster and social issues. Progress in Disaster Science 10: 1-6.

Suzuki, Kazuto. 2020. Pandemic shows Japan needs to figure out how to learn and prepare. The Japan Times, July 20. Available online: https:/ / www.japantimes.co.jp/opinion/2021/07/20/commentary/japan-commentary/japan-last-minute-vaccines/ (accessed on 31 July 2021).

Takahashi, Ryusei. 2021. COVID-19 spreads quietly in the shadow of the Olympics. The Japan Times, July 26. Available online: https: / / www.japantimes.co.jp/news/2021/07/26/national/olympic-virus-cases-july-26/ (accessed on 31 July 2021).

Takenaka, Kiyoshi. 2020. Two Japanese evacuated from Wuhan have pneumonia symptoms, second flight being dispatched. Reuters, January 28. Available online: https:/ / www.reuters.com/article/uk-china-health-japan/two-japanese-evacuated-from-wuhanhave-pneumonia-symptoms-second-flight-being-dispatched-idUKKBN1ZS02T (accessed on 31 July 2021).

Talmadge, Eric. 1996. Japan Faces AIDS Scandal. Available online: http://www.aegis.com/news/ap/1996/AP961211.html (accessed on 31 July 2021).

Todaro, Michael P. 1969. A Model of Labor Migration and Urban Un-employment in Less Developed Countries. American Economic Review 59: 138-48.

Tsuda, Takeyuki. 2000. Migration and Alienation: Japanese-Brazilian Return Migrants and the Search for Homeland Abroad. The Center for Comparative Immigration Studies Working Papers no. 24. San Diego: The Center for Comparative Immigration Studies/University of California at San Diego.

Tsuda, Takeyuki. 2003. Strangers in the Ethnic Homeland: Japanese Brazilians Return Migration in Transnational Perspective. New York: Columbia University Press.

US Bureau of Democracy, Human Rights, and Labor. 2018. International Religious Freedom Report for 2018. Washington, DC: United


$\backslash$ guilsinglrightJAPAN-2018-INTERNATIONAL-RELIGIOUS-FREEDOM-REPORT.pdf (accessed on 31 July 2021).

Vatican News. 2020. Arcebispo de Tóquio: Oportunidade para redescobrir poder da oração e aprofundar vida espiritual. Vatican News, March 26. Available online: https:/ /www.vaticannews.va/pt/igreja/news/2020-03/arcebispo-toquio-coronavirus-redescobrirpoder-oracao.html (accessed on 31 July 2021).

Yamanaka, Keiko. 2003. Feminization of Japanese Brazilian Labor Migration to Japan. In Searching for Home Abroad: Japanese Brazilians and Transnationalism. Edited by Jeffrey Lesser. Durham: Duke University Press, pp. 163-200.

Yamashiro, Jane H. 2008. Nikkeijin. In Encyclopedia of Race, Ethnicity, and Society. Edited by Richard T. Schaefer. Thousand Oaks: Sage, pp. 983-85.

Yamashiro, Jane H., and Hugo Córdova Quero. 2012. Negotiating Unequal Transpacific Capital Transfers: Japanese Brazilians and Japanese Americans in Japan. In Transnational Crossroads: Remapping the Americas and the Pacific. Edited by Camilla Fojas and Rudy Guevarra. Lincoln: University of Nebraska Press, pp. 403-26.

Yamawaki, Keizo. 2007. The Challenges of the Japanese Social Integration Policy. Paper presented at the DIJ Forum of the German Institute for Japanese Studies, Yotsuya, Tokyo, Japan, April 12. 